GEAP-5701

AEC RESEARCH AND DEVELOPMENT REPORT MARCH 1969
RECEIVED BY DTIE OCT1 59969

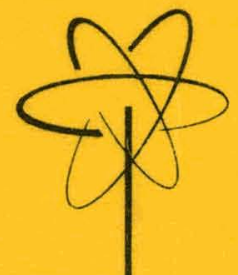

\section{FUEL HANDLING AND OTHER TESTS IN THE SEFOR REFUELING CELL MOCKUP}

A.G. STEAMER

G.V. BRYNSVOLD

L.C. FRANX

U.S. ATOMIC ENERGY COMMISSION

CONTRACT AT $(04-3)-540$

BREEDER REACTOR DEVELOPMENT OPEPATION GENERAL (8?6) ELETRIC SUNNYVALE, CALIFORNIA 


\section{DISCLAIMER}

This report was prepared as an account of work sponsored by an agency of the United States Government. Neither the United States Government nor any agency Thereof, nor any of their employees, makes any warranty, express or implied, or assumes any legal liability or responsibility for the accuracy, completeness, or usefulness of any information, apparatus, product, or process disclosed, or represents that its use would not infringe privately owned rights. Reference herein to any specific commercial product, process, or service by trade name, trademark, manufacturer, or otherwise does not necessarily constitute or imply its endorsement, recommendation, or favoring by the United States Government or any agency thereof. The views and opinions of authors expressed herein do not necessarily state or reflect those of the United States Government or any agency thereof. 


\section{DISCLAIMER}

Portions of this document may be illegible in electronic image products. Images are produced from the best available original document. 
GEAP-5701

$\mathrm{AEC}$ Research and Development Report

March 1969

FUEL HANDLING AND OTHER TESTS

IN THE SEFOR REFUELING CELL MOCKUP

By

A. G. Steamer, Task Leader

G. V. Brynsvold

L. C. Franckx

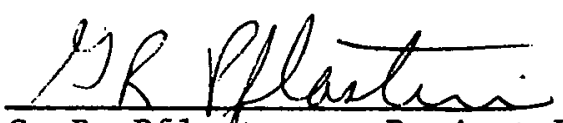

G. R. Pflafterer, Project Engineer SEFOR Research and Development Program. Breeder Reactor Development Operation

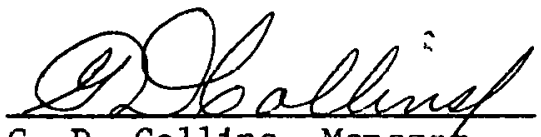

G. D. Collins, Managet

Sodium Technology Subsection

Prepared for the

Southwest Atomic Energy Associates

for Transmittal to the

U.S. Atomic Energy Commission

Under Contract AT (04-3)-540

Printed in U.S.A. Available from the

Clearing House for Federal Scientific and Tecbnical Information

National Bureau of Siandards, U.S. Department of Commerce

Springfield, Virginia

Price: $\$ 3.00$ per copy

5945-BRDO-77

160-GA-9/69

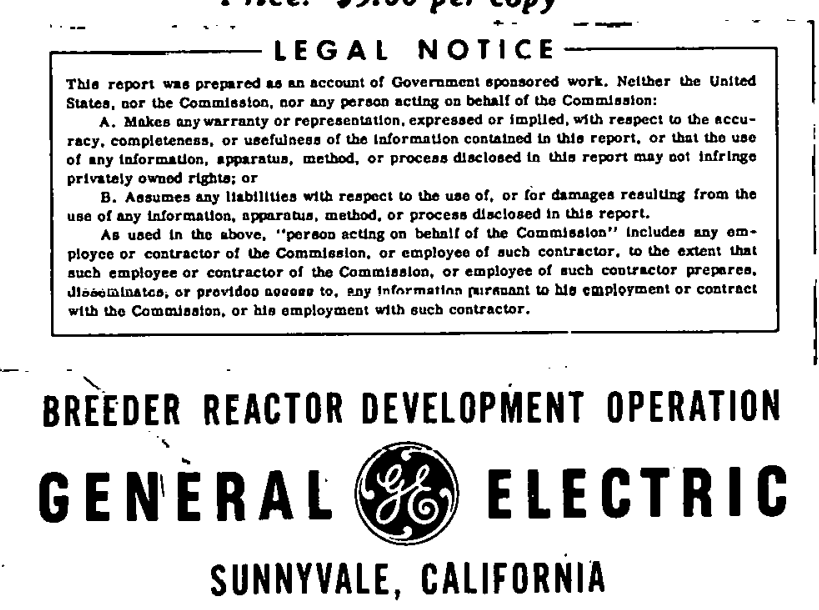




\section{LEGAL NOTICE}

This report was prepared as an account of Governmest sponsored work. Neitber the United States, nor the Commission, nor any person acting on bebalf of the Commission:

A. Makes any warranty or representation, expressed or implied, with respect to the accuracy, completeness, or usefulness of the information contained in this report, or that the use of any information, apparatus, metbod, or process disclosed in this report may not infringe privately owned rights; or

B. Assumes any liabilities with respect to the use of, or for damages resulting from the use of any information, apparatus, method, or process disclosed in this report.

As used in the above, "person acting on behalf of the Commission" includes any employee or contractor of the Commission, or employee of sucb contractor, to the extent that sucb employee or contractor of the Commission, or employee of sucb contractor prepares, disseminates, or provides access to, any information pursuant to bis employment or contract witb the Commission, or bis employment with such contractor. 
ABSTRACT

SECTION

INTRODUCTION

1-1

SECTION II

MOCKUP DESIGN

$2-1$

SECTION III

CONSTRUCTION

3-1

3.1 Initial Structure for Dry Testing

3-1

3.2 Stee1-Lined Enclosure

3-2

SECTION IV

TESTING

4-1

4.1 Preliminary

4-1

4.1.1 Reactor Head and Fuel Storage Tank

4-1 E1astomer Seals

4.1.2 Sodium Vapor Contro1

4-1

4.1.3 Fuel Rod Grapple

4-4

4.1.4 Half-Ton Grapple Tests

4-6

4.2 Dry Mockup Tests

$4-8$

4.2.1 Equipment Location Trials

4-8

4.2.1.1 Cell View Windows

$4-8$

4.2.1.2 Closed-Circuit Televiston

4-9

4.2.1.3 Fuel Storage Tank

4-9

4.2.1.4 Master-Slave Manipulator

4-10

4.2.1.5 Mirrors

4-10

4.2.1.6 Ce11 Lights

4-11

4.2.2 Man Access System

4-11

4.2.3 Periscope

4-14

4.2.4 Fuel Rod Dimensional Inspection

4-15 Equipment:

4.2.5 Vesse1 Head Lift Sling

4-16

4.2.6 General Purpose Grapple

4-16

4.2.7 Argon Recirculation System

4-20 
$\frac{\text { TABLE OF CONTENTS }}{(\text { CONTd.) }}$

(Contd.)

Page

4.2.8 Instrumented Fuel Assembly 4-21

4.2.9 Closed-Circuit Television 4-22

4.2.10 Multi-ton Grapple 4-25

4.2.11 Half-ton Hoist 4-26

4.2.12 Fuel Storage Tanks 4-26

4.2.13 Grapple Storage Racks 4-26

4.2.14 Fuel Rod Assembly, Disassembly, and 4-27 Canning Equipment

4.2.15 Mirrors 4-27

4.3 Wet Mockup Testing 4-28

4.3.1 Tnstrumented Fuel Assembly 4-28

4.3.2 Sodium Sampling 4-28

4.3.3 Vertical Transfer 4-30

4.3.4. Thru-Head Refueling 4-30

4.3.5 Fuel Inspection 4-32.

4.3.6 Fue1 Rod Disassemb1y, Canning and 4-34 Re-Assembly

4.3.7 Man Access System 4-36

4.3.8 Head Removal-Replacement 4-39

4.3.9 Periscope : 4-41

4.3.10 Grapples 4-41

4.3.11 Cell Lights 4-42

4.3.12 Sodium Leve1 Adjustment for Determining 4-42 Fuel Rod Elevation in the SEFOR Vesse1

4.3.13 Refueling Cell Argon System 4-52

4.3.14 Sodium Vapor Deposition 4-53

SECTION $V$ CONCLUSION

REFERENCES - -1-

DISTRIBUTION - -2- 


\section{LIST OF ILLUSTRATIONS}

Figure No.

Title

$\underline{\text { Page }}$

$2-1$

Refueling Cell Mockup and Equipment

$5-2$

$2-2$

Ce11 Outer Structure

$2-2$

$2-3$

Crane Repair Bay

$2-3$

3-1

Man Access Panel - Outside Cell

3-3

3-2

Man Access Panel - Inside Cell

3-4

3-3

Mockup Vessel in Place and Partially Loaded

3-5

4-1 with Dumny Fuel

4-2

4-3

Sodium Evaporation Rates

4-3

Interior of Mockup Vessel Assembly Through

4-23

Television

4-4

Crane Cable Repair Work as Seen Via Television

4-24

Instrumented Fuel Assembly in Transit

4-29

4-5

Filled Sodium Sample Cup in Transit from Vesse1

4-31

$4-6$

Fuel Rod After Withdrawal from Vessel - As Seen

4-33

4-7

Via Periscope

4-8

Operator W1ping Rod Prior to Inspection

4-35

Operators in Suits During Crane Cable Repairs

4-37

4-9

Sodium Surface at Fuel Rod Tops

4-40

4-10

Level Gauge Test Fixture - Prior to Insertion in

4-44 Mockup Vesse1

4-11

Level Gauge Test Fixture - Prior to Insertion in

$4-45$ Mockup Vesse1

4-12

Level Gauge Test Fixture - Two Rod Tops Protruding

$4-47$ Above Sodium Surface

$4-13$

Level Gauge Test Fixture - Six Rod Tops Protruding Above Sodium Surface.

Level Gauge Test Fixture - Al1 Seven Rod Tops 4-50

4-15 Protruding Above Sodium Surface

Level Gauge Test Fixture - Handle Regions Fully

4-51

Exposed Above Sodium Surface 


\title{
ABSTRACT
}

\begin{abstract}
A full-scale mockup of the SEFOR refueling cell was constructed to test the fuel handling operations under typical operating conditions. Initial equipment tests were performed with air in the refueling cell to determine optimum equipment locations and viewing facilities, and to check equipment operation. The cell was next filled with argon and the mockup reactor vessel and sodium service system were filled with sodium, which simulated all but the nuclear environment typical of reactor operation. Tests were then performed to check the performance of the argon purification system, fuel handling operations, sodium sampling, reactor head removal and replacement, and sodium vapor deposition in the cell.
\end{abstract}


GEAP-5701

\section{SECTION I}

INTRODUCTION

This report describes results of tests performed with the mockup of the refueling cell and fuel handling equipment proposed for the Southwest Experimental Fast Oxide Reactor (SEFOR).

The Southwest Experimental Fast Oxide Reactor (SEFOR) is a $20 \mathrm{MW}(\mathrm{t}$ ) fast spectrum reactor fueled with mixed $\mathrm{PuO}_{2}-\mathrm{UO}_{2}$ and cooled with sodium. SEFOR will have characteristics similar to large, soft spectrum fast breeder reactors fueled with mixed $\mathrm{PuO}_{2}-\mathrm{UO}_{2}$. Economic studies of these large power reactors indicate significant potential for producing low cost power. SEFOR will be used to obtain physics and engineering data at fuel compositions, temperatures, and crystalline states characteristic of power reactor operating conditions. SEFOR is particularly designed for the systematic determination of the Doppler coefficient of reactivity at temperatures up to the vicinity of fuel melting.

The SEFOR Project consists of two major parts: the design and construction of the reactor and a related research and development program. Funds for the design and construction of the facility are being provided by the Southwest Atomic Energy Associates (a group of seventeen investor-owned utility companies located In the South and Southwest part of the United States), together with the Karlsruhe Laboratory of the Federal Republic of Germany, Euratom, and the General Electric Company . 
The United States Atomic Energy Commission is supporting the research and development program. The $R$ and $D$ Program consists of two phases:

Phase I - Pre-operational Research and Development

Phase II - Post Construction Research and Development

This report describes work performed under Task 7, Fuel Handing, in Phase I of the Research and Development Program. This work was carried out concurrently with the plant design of the SEFOR refueling cell. The primary objectives were to assist in developing adequate refueling concepts, to confirm overall arrangements, and to environmentally proof-test major pieces of refueling and fuel inspection equipment.

Specific tests planned to be performed in the cell mockup were as follows:

a). Arrangement of cell structure;

b). Arrangement of cell interior equipment;

c). Evaluate various viewing aid devices;

d). Evaluate remotely operated transport and grappling devices;

e). Investigate potential sodium vapor transport problems;

f). Evaluate gas flow and gas purification system for the refueling cell;

g). Develop cell illumination system;

h). Evaluate all phases of fuel transfer including preparation for shipment;

1). Develop and evaluate maintenance equipment and procedures to be used during man entry to the cell; 
j). Develop and evaluate remotely operated emergency handling equipment and procedures;

k). Proof test fuel inspection and processing equipment planned for use in the SEFOR plant cell; and

1). Install and test prototype in-core instrumentation planned for use during the operation of SEFOR.

The reader is referred to the following SEFOR R\&D Quarterly Progress Reports for details not completely reported here:

$$
\begin{aligned}
& \text { GEAP-4994 - November, } 1965 \\
& \text { GEAP-5108 - February, } 1966 \\
& \text { GEAP-5160 - May, } 1966 \\
& \text { GEAP-5208 - August, } 1966 \\
& \text { GEAP-5442 - February, } 1967 \\
& \text { GEAP-5498 - May, } 1967
\end{aligned}
$$




\section{MOCKUP DESIGN}

The SEFOR refueling cell is a rectangular, steel-lined room, 17 feet long, 13-1/2 feet wide, and 28 feet high. Cantilevered crane repair bay and a facility for transferring irradiated fuel between the cell and a fuel shipping cask are located at one end of the cell. The lower portion of the cell encompasses the reactor head, a separate fuel storage tank, and various other refueling, fuel inspection and fuel processing equipment. General in-cell remote handling ability is provided by a bridge crane and grapple system. (See fold-out Figure 2-1 at end of report, and Figures 2-2 and 2-3.)

The mockup structure was planned to duplicate the plant concept in full scale and to ultimately utilize all major items of fuel handling equipment.

The design of the refueling cell mockup commenced in May, 1964. Test objectives were most efficiently achieved by initially performing dry (no sodium) tests followed by wet testing in which all aspects of plant refueling conditions other than radiation effects were established.

The original concept was to carry out the dry tests in a full-scale wood mockup which later was to be replaced by a gas-tight steel cell for the environmental phase of the program. However, it was determined that fabrication costs as well as construction time could be reduced by planning a single, dual purpose, full-scale structure which could be modified during the program to effect both dry and wet testing. This latter concept was used. 


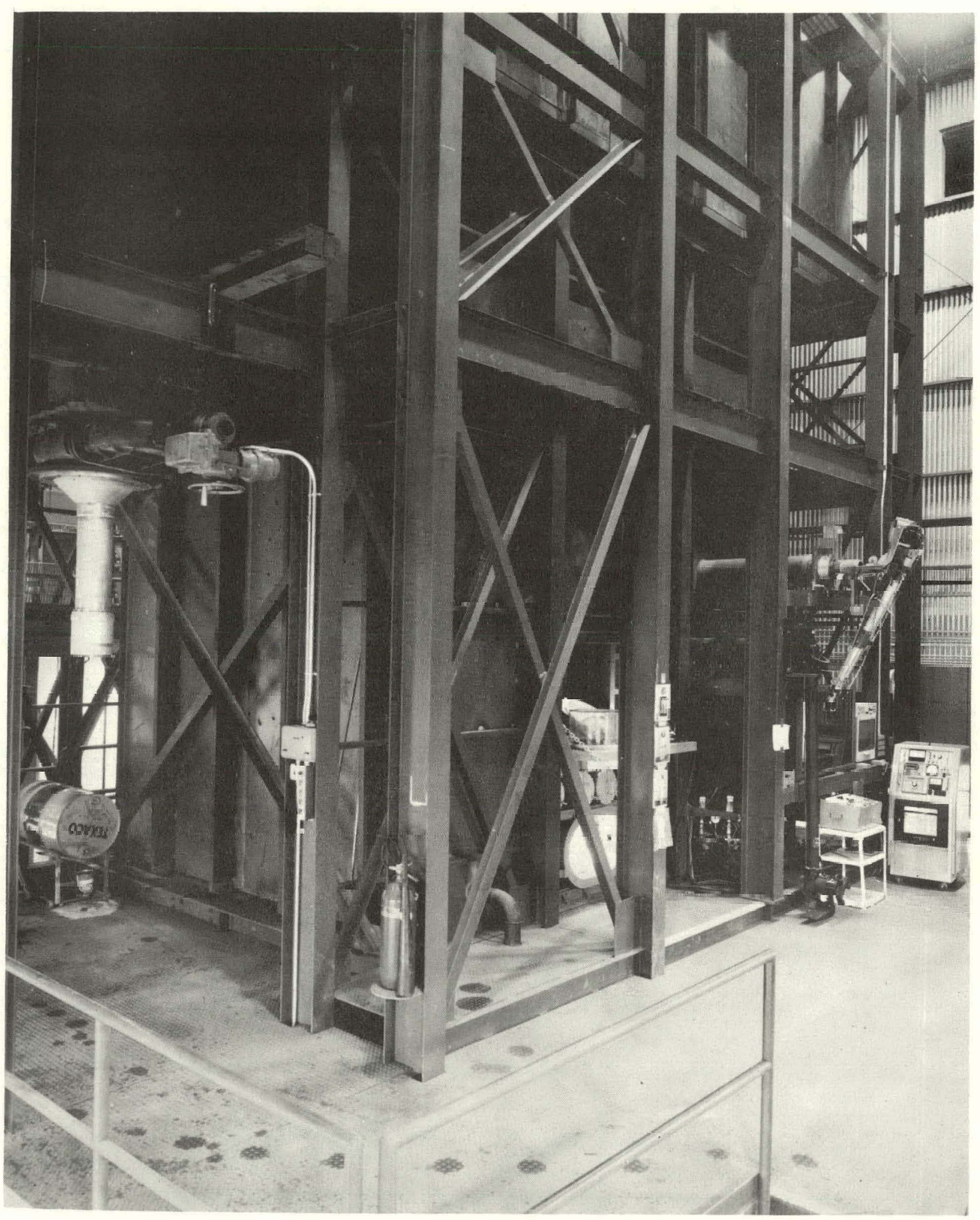

FIGURE 2-2. CELL OUTER STRUCTURE 
GEAP-5701

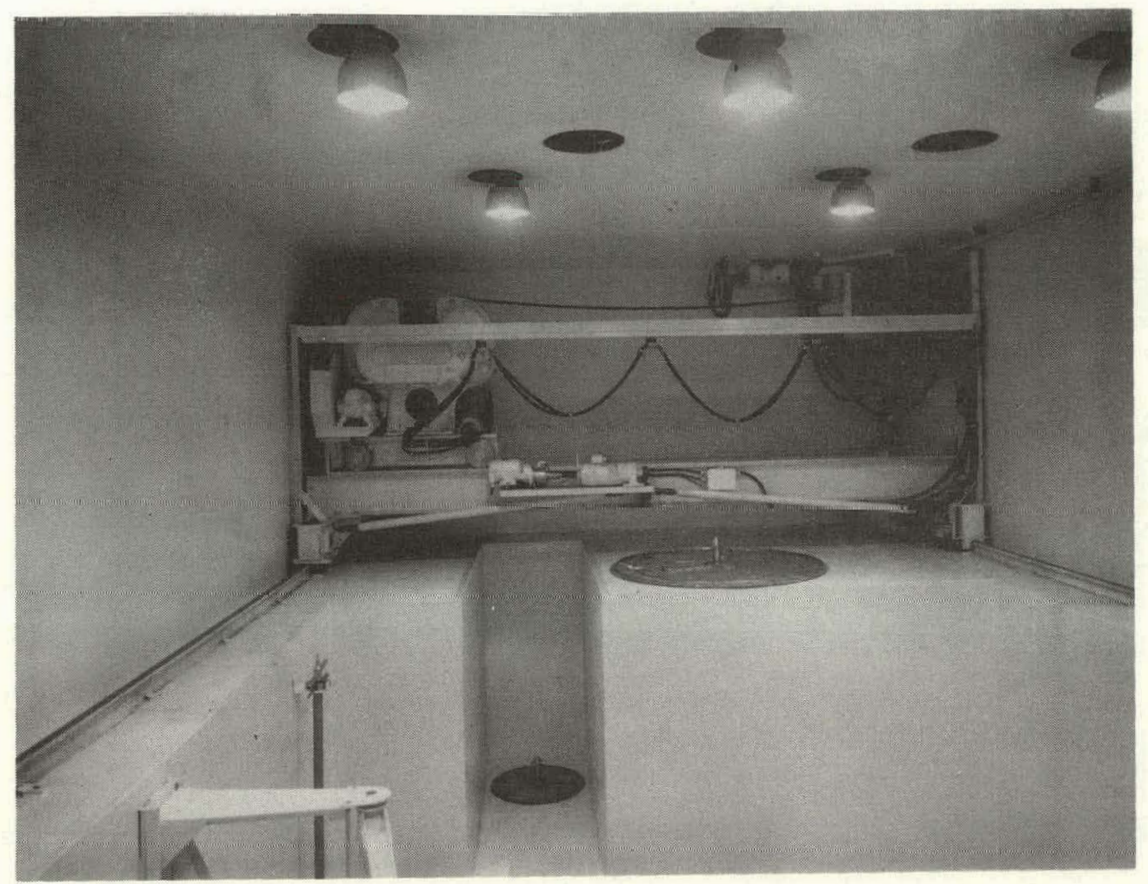

FIGURE 2-3. CRANE REPAIR BAY 
To accommodate both the stationary and dynamic loads in the mockup, a steel frame structure of considerable strength was necessary. An architectengineer was engaged to design the basic skeletal steel structure in compliance with. state and local codes. (See Figure 2-2.) 


\section{SECTION III}

\section{CONSTRUCTION}

\subsection{INITIAL STRUCTURE FOR DRY TESTING}

Construction of the cell mockup began in April, 1965. A basic skeletal steel structure was first established to support the various stationary and dynamic loads anticipated. Major loads to be imposed were a 10-ton bridge crane, steel dummy reactor vessel, oil-filled dummy view windows and certain shield covers associated with the reactor vessel and fuel storage. The cell floor was covered with plywood and the cell walls were plywood paneled to a height of 16 feet above the cell deck. That part of the SEFOR plant equipment to be used in the dry tests, i.e. master-slave manipulator, periscope, crane, lights, television, and wood mockups of the remaining in-cell equipment were fabricated and installed. All mockups, cell floor and walls were painted to simulate the stainless steel of the actual equipment and the white epoxy paint of the cell interior. Location trials were conducted and the design altered to reflect the results of the trials. During these initial tests, the cell lights were mounted on the plywood walls at an elevation 10 feet above the cell floor and a sheet metal skirt of the vessel configuration plus a 12-inch pipe complete with support plate, channels, tightener sleeves and dummy fuel rods was located in the vessel cavity area. The dummy oil-filled windows were installed on adjustable supports. These equipment location tests were completed in December, 1965. The mockups, easily removable plant equipment, and temporary paneling were removed at the conclusion of initial dry testing in preparation for the second phase of construction and testing. 
The installation of the in-cell crane preceded the fabrication of the cell. steel liner. Following installation and check-out of the crane in February, 1966, the cell was fully enclosed with the exception of the east wall (open to allow installation of the reactor vesse1) and the floor area surrounding the mockup reactor vessel cavity. Cell wall penetrations were fabricated for the masterslave manipulator and periscope. These penetrations and the man access panel frame were installed along with the liner. The man access panel was received and installed during July, 1.966 (Figures 3-1 and 3-2). By October, 1966, the life-support equipment installation was completed and the system checked out. The reactor mockup vessel (Figure 3-3) was received in August, 1966, installed and final closure of the cell was made. The argon recirculation ducting and the purification line were connected to the cell, and the argon system operation was checked. The cell lights were installed, the crane electrical leads were sealed at the cell liner penetration and crane operational checks were made.

The next step in preparation for further operation was to clean and paint the cell interior with the identical materials selected for the SEFOR cell. Amercoat $\$$ k6, a commerical radiation-resistant epoxy paint was applied to all interfor surfaces of the cell walls, ceiling and floor.

The installation and check-out of equipment, including both temporary wooden mockups and actual plant equipment, spanned a period of twenty months. The cell mockup was ready for environmental (with sodium) testing in February, 1967.

As the remaining SEFOR plant equipment became available, it was installed and checked out. 


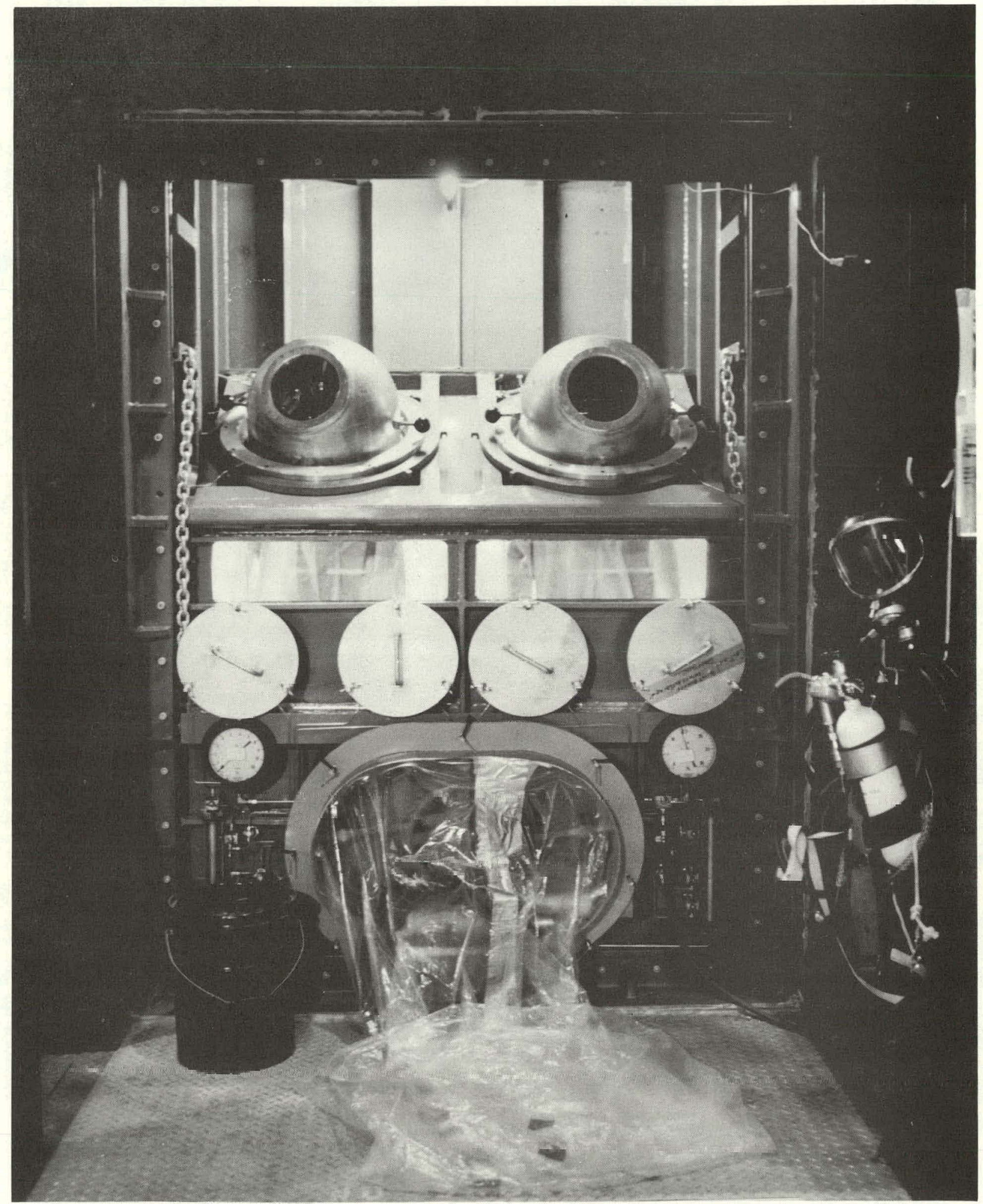

FIGURE 3-1. MAN ACCESS PANEL - OUTSIDE CELL 


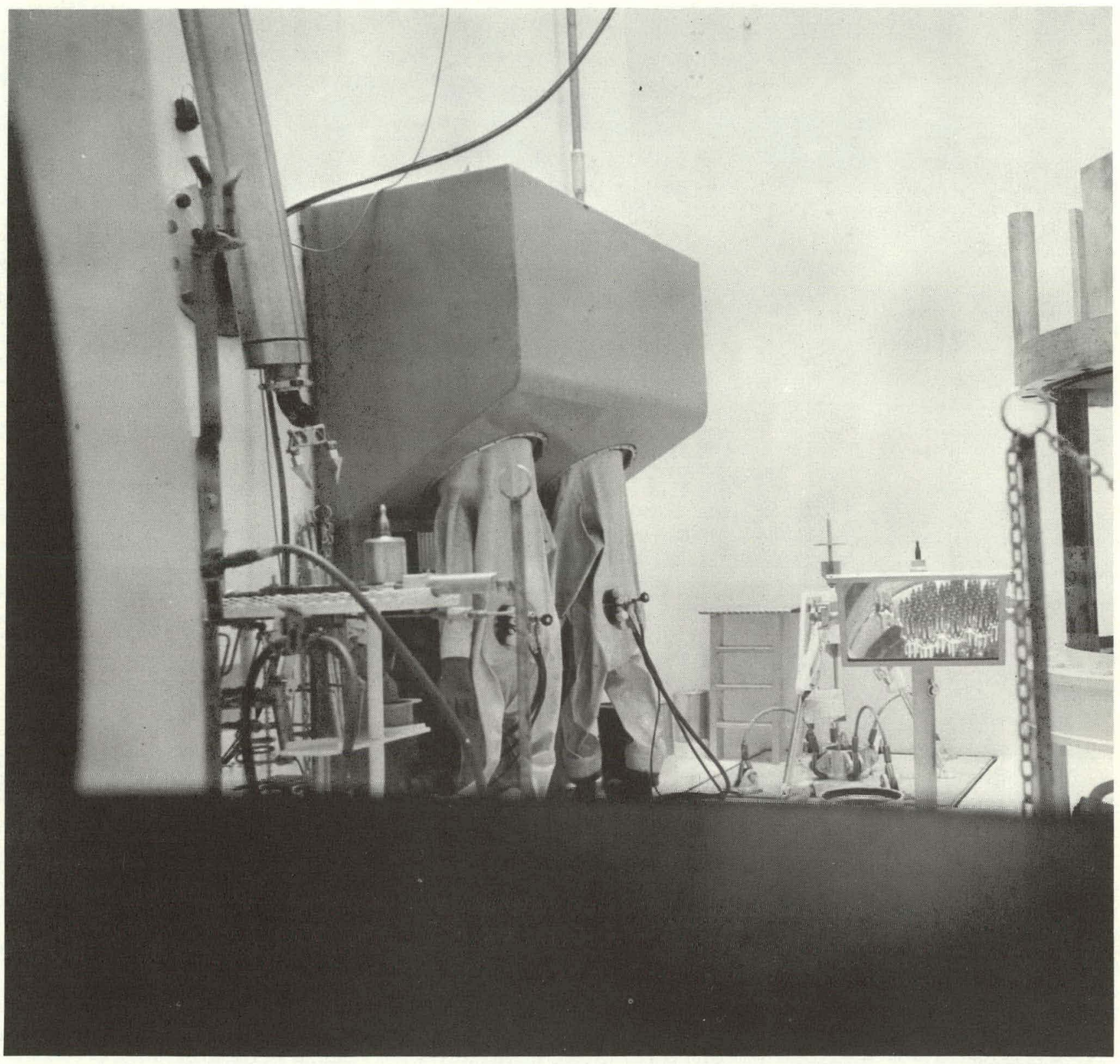

FIGURE 3-2. MAN ACCESS PANEL - INSIDE CELL 


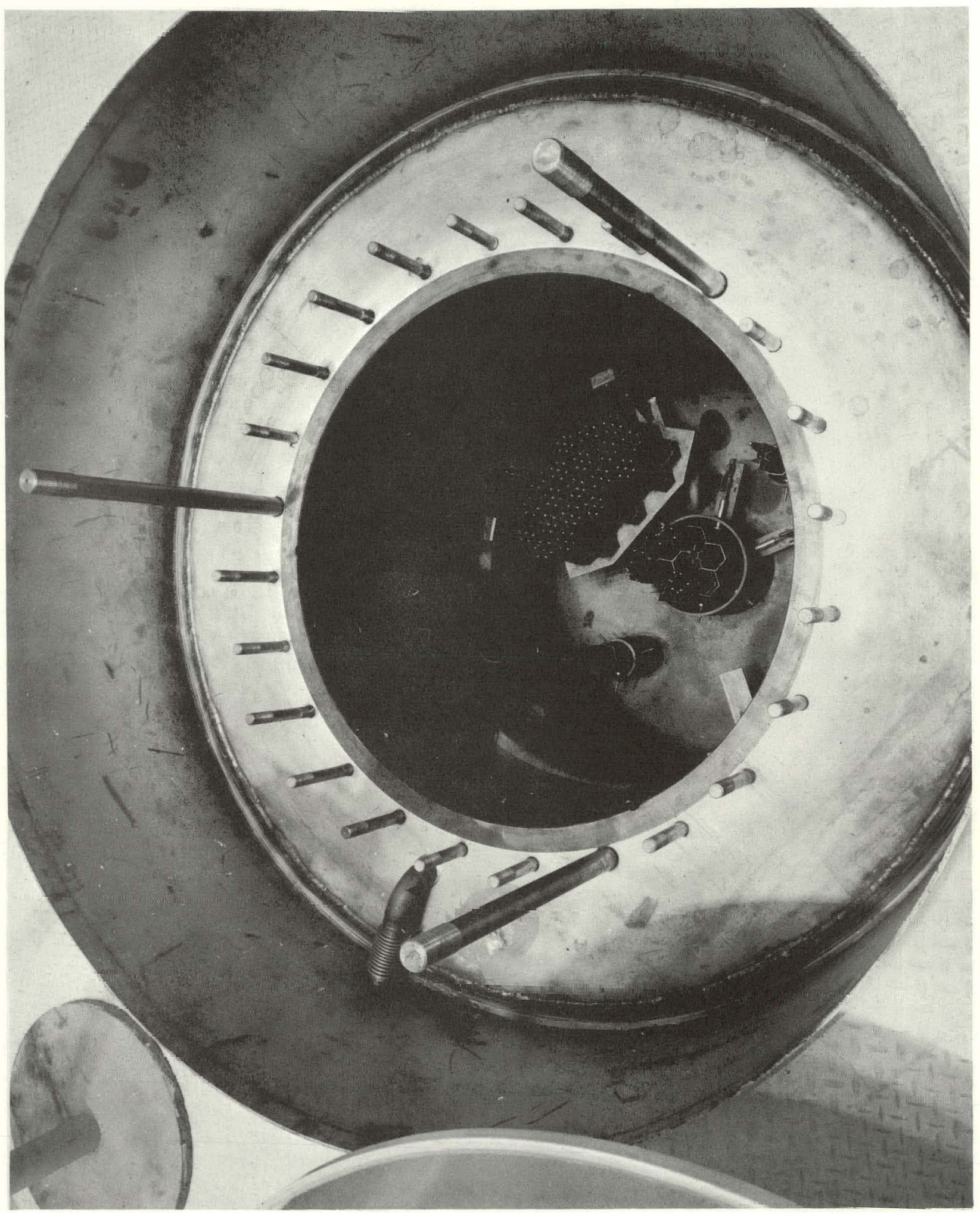

FIGURE 3-3. MOCKUP VESSEL IN PLACE AND PARTIALLY LOADED WITH DUMMY FUEL 
GEAP -5701

SECTION IV

TESTING

\subsection{PRELIMINARY}

\subsubsection{Reactor Head and Fuel Storage Tank Elastomer Seals}

A small scale apparatus was fabricated to test a variety of silicone elastomer seals being considered for the reactor head and for the wet fuel storage tank covers. These seals included solid and hollow 0-ring types, split seals and hollow 0-rings with an internal, flat, strip-wound spring. The results of the tests indicated a continuous, split ring, silicon rubber gasket would contain up to 15 psig utilizing only the dead weight of the fuel storage tank shield covers for compression. During the test program consideration of these seal materials for the reactor was dropped, thus, further test work with elastomers under reactor vessel operating conditions was not required.

\subsubsection{Sodium Vapor Contro1}

During operations with the reactor vessel cover removed, the sodium surface is open to the refueling cell argon atmosphere. One of the questions arising early in the design of SEFOR was how much sodium could be expected to evaporate into the cell and subsequently condense on optical surfaces or close fitting mechanisms.

Although plans were made at the start of the project to build the fullscale mockup of the cell to observe, among other things, the deposition of sodium vapor in the celi, several small-scale experiments were conducted to develop early information on evaporation rates from a pool of sodium and from heated sodium-wetted rods. In this experiment, a 6-inch-diameter pipe was 
used to simulate the sodium pool in the SEFOR vessel. The pipe return was enclosed in a bell $\mathrm{j}$ ar simulating the refueling cell. The sodium surface area and dimensions of the gas space in the model were made in proportion to those in the SEFOR design. Measurements of sodium evaporation were made by washing the bell $\mathrm{j}$ ar with a known volume of dist1lled water after each test and analyzing the wash with flame-spectrometry techniques to determine the sodium content.

The experiments were conducted with the temperature of the sodium pool varled from $350^{\circ}$ to $600^{\circ} \mathrm{F}$ while the argon temperature was maintained in the vicinity of $100^{\circ} \mathrm{F}$. Testing was conducted both with static argon and with a net flow of dry argon through the bell jar.

Data from these experiments correlated reasonably well with the dimensionless expression developed by Boelter, et al, ${ }^{(1)}$ for the evaporation of water from a horizontal quiet surface into air, as shown in Figure 4-1. These experimental results have been used to predict evaporation rates in SEFOR, and the predictions indicate that with the sodium temperature maintained below $400^{\circ} \mathrm{F}$ during operations with vessel cover removed, approximately 10 grams of sodium may be expected to evaporate during the three years of planned SEFOR operations.

Additional experiments were conducted with heated rods to simulate evaporation of sodium from fuel rods after removal from the core. These measurements indicate that a film approximately 0.7 mil-thick may be expected to reamin on a wetted rod after natural drainage. The evaporation rates from the heated rod were found to be similar (within an order of magnitude) to that measured from the pool of sodium. 


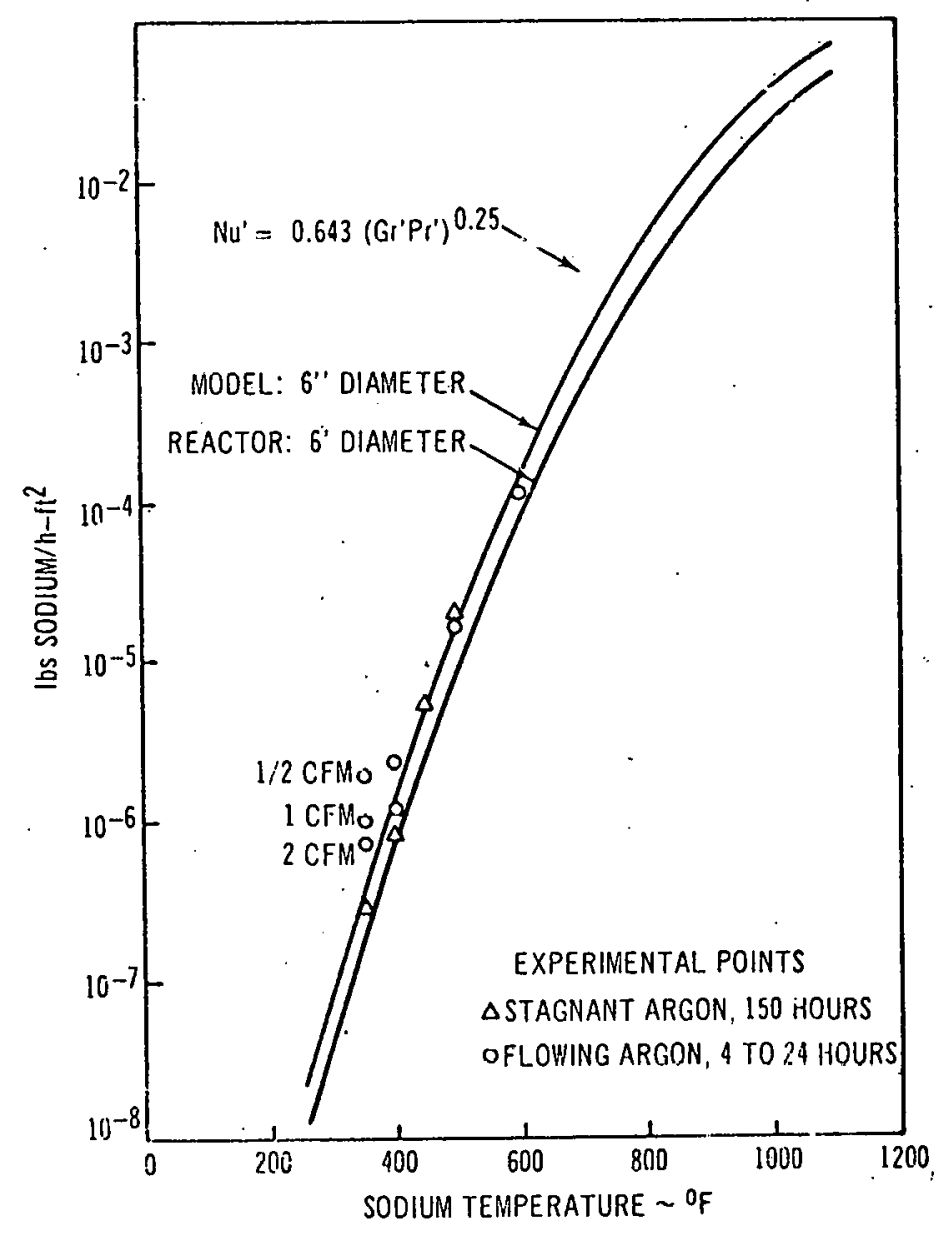

FIGURE 4-1. SODIUM EVAPORATION RATES 
Results of these experiments provided important guidance during the early design phase before the full-scale mockup of the refueling cell could be built and tested.

\subsubsection{Fuel Rod Grapple}

Preliminary tests were conducted on the fuel rod grapple mechanism to evaluate operation of the device prior to use in the mockup test facility. These consisted of fuel rod handle and grapple component load tests as well as environmental tests of the grapple mechanism.

When using the fuel rod grapple, the fuel rod lifting force is transmitted to the grapple assembly via locking balls. This presents a point contact force application between the grapple sleeve-to-ball and ball-to-fuel rod handle. Tests were therefore conducted to determine the effects of various loading conditions on this ball lock attachment. Applied tensile loads on the grappleto-fuel rod handle combination showed slight dimpling of the fuel rod handle at 50 pounds (greater than 3 times the fuel rod weight) and increasing dimpling as forces were increased to 350 pounds (operating load range of the fuel grapple is 300 pounds). The grapple mechanism was also operated to lock onto the cylindrical head region of the handle instead of under the head as is required for proper engagement. This caused stalling of the gear motor and noticable dimpling of the handle. However, repeated stalling operations caused no damage to the grapple parts and the grapple mechanism was readily unlocked from this stalled condition. Furthermore, dimpling of the handle resulting from the above tests did not interfere with either the grapple attachment or with assembly of the extension rod onto the fuel rod handle. 
Compression tests were conducted on the stellite balls to provide assurance that they would not fracture under any operational conditions. The failure load determined by compressing the balls between 2 tool steel anvils ranged from 2300 to 2400 pounds. This is about twice the maximum load that could be applied during improper grapple locking operation wherein the balls are forced against the cylindrical head of the handle as described in the preceeding paragraph. No loading occurs during normal grapple operation and only approximately 150 pounds is applied to each ball when lifting at the maximum load rating of the grapple.

In preparation for the environmental tests, a torque test was conducted on the gear motor used to actuate the grapple mechanism. From this information, a torque versus voltage curve was plotted. This was subsequently utilized during data reduction of later tests where the applied voltage was recorded and thus used to determine the force required to actuate the grapple mechanism.

Environmental tests (sodium pool and argon cover gas) were conducted in the modified sodium vapor test apparatus. These tests were conducted to simulate lifting a sodium-wetted fuel rod from the reactor at $400^{\circ} \mathrm{F}$ and moving it to a work station in the refueling cell during which time the rod could cool down to cell temperature $\left(<100^{\circ} \mathrm{F}\right)$. The objective, therefore, was to investigate the effects of the frozen sodium on the grapple mechanism operation.

The first test sequence consisted of: (1) wetting the fuel rod handle with sodium at $400^{\circ} \mathrm{F}$, (2) lowering the sodium to expose the handle, (3) lowering and locking the grapple on the handle, (4) allowing the system to cool down thus freezing the sodium, (5) unlocking the grapple, and (6) lifting the grapple free of the fuel rod handle. The results of these tests revealed a gear motor torque requirement ranging from 20 to 40 inch-pounds (about $4 \%$ of the gear motor torque capability), and essentially no sticking force when lifting the grapple free of the fuel rod handle. 
The procedure was altered for the next test sequence in an attempt to accelerate any sodium build-up or other exposure effects. This change consisted of submerging the grapple end into $400^{\circ} \mathrm{F}$ sodium and locking into the fuel rod handle before lowering the sodium level. Results of these tests were essentially the same as the first test sequence. These results plus examination of the grapple parts after completion of the tests indicated very little sodium wetting of the nitrided grapple parts.

Automatic cycling tests were conducted by locking and unlocking the grapple from the sodium-wetted fuel rod handle. These tests were run with the grapple mechanism in an argon atmosphere above the exposed $400^{\circ} \mathrm{F}$ sodium pool. The only problem that was brought out during these tests was that caused by the coastdown of the gear motor which actuates the grapple. The coast-down effect had to be snubbed by the grapple structure which resulted in adjustment problems and highly stressed parts. A "weak link", in the form of a spiral pin (a solid pin is utilized in the grapple as assembled for plant use) connecting the gear motor drive coupling to the drive shaft, failed after 6700 cycles due to the snubbing action. The limit switch adjustment (and thus drive motor shut-off) and undue structural loading problems were eliminated by adding an electrically actuated brake to the drive motor. This modified gear motor was tested later in conjunction with the half-ton grapple tests.

\subsubsection{Half-Ton Grapple Tests}

Tensile tests and environmental tests were conducted on the collet finger grapple device prior to use of this device in the refueling cell mockup tests. For the tensile tests, the grapple device and fuel rod handle were mounted in a tensile testing machine which loads up to 1500 pounds (50\% over-rated 1oad) were applied. No damage or permanent distortion of the loaded parts resulted from these tests. 
Environmental tests, similar to those for the fuel grapple mechanism, were conducted in the modified sodium vapor test apparatus. This test arrangement utilized the fuel rod grapple drive mechanism with the collet finger grapple end, thereby enabling testing of the brake-gear motor as well as the half-ton grapple end.

The environmental tests (argon cover gas and sodium pool) included operational steps to investigate adherence of the grapple to a sodium-coated fuel rod. Initial tests were conducted by: (1) soaking (and thus wetting) the fuel rod handle, (2) lowering the sodium to expose the handle, (3) attaching the grapple, (4) allowing the system to cool thus freezing the sodium, (5) unlocking the grapple, and (6) lifting the grapple free of the fuel rod handle. The results of these tests revealed a gear motor torque requirement ranging from 18 to 27 inch-pounds, and a force less than 1.5 pounds to break any sodium bond that may have existed between the grappie and fuel rod handle. The procedure was then altered in an attempt to accelerate any sodium build-up or exposure effects. This change consisted of submerging the grapple end in the $400^{\circ} \mathrm{F}$ sodium and latching onto the fuel rod handle before lowering the sodium level. Results of these tests were essentially the same as the initial tests. These results plus examination of the grapple parts after completion of the tests indicated very little sodium wetting of the nitrided grapple parts.

Automatic cycling tests (approximately 13,500 cycles) were run locking (and unlocking) the grapple to the sodium-wetted fuel rod handle in the argon atmosphere above the exposed $400^{\circ} \mathrm{F}$ sodium pool. The mechanism performed well during these tests. However, the following two gear motor problems were found: 
1. The brake and protective shroud mounting were not adequate to assure reliable continuous operation. This was corrected by the addition of small dowel pins to hold the position once the brake was adjusted.

2. The automatic cycling tests were terminated when one of the power leads to a motor winding shorted out. This failure was repaired by the vendor.

\subsection{DRY MOCKUP TESTS}

The dry mockup testing encompassed the initial equipment location trials, equipment check-out, equipment modifications where required, and the development of certain operating procedures.

\subsubsection{Equipment Locat1on Trials.}

The results and conclusions drawn from preliminary equipment location trials are:

\subsubsection{Cell View Windows}

Upon installation of two oll-filled windows simulating the viewing capability of plant dense glass windows, it was found necessary to apply a "Sun Gold Stop" plastic coating to the inside face cover glass. This reduced total visible light transmission to $35 \%$ as anticipated for the plant windows and resulted in a yellowing effect also characteristic of hi-density lead glass.

Initial location of the fuel inspection window did not provide for proper viewing of the fuel inspection equipment located in the corner of the cell. The window was relocated 4 inches westward toward the inspection station to provide adequate coverage. At the same time this window was elevated 6 inches to improve general viewing in the cell. 
The reactor service window was maintained on the reactor centerline, and at its original elevation to favor the downward view into the reactor. It is 6 inches lower than the fuel inspection window.

\subsubsection{Closed-Circuit Television}

Initial operations of the remotely operated T.V. camera with pan and tilt drive mount utilized a standard camera tripod. Though the tripod could be relocated at various floor positions within the cell it was quickly apparent that its most useful and convenient location would be on a wall mounted, remotely driven boom. This latter arrangement was provided for subsequent test phases.

\subsubsection{Fue1 Storage Tank}

It was observed that the lifting sling cables for the fuel storage tank cover form a relatively high arc when the sling lift plate is in the storage position. The cables are thus extended beyond the spacing blocks used to separate the covers when stored upon one another while working in one storage tank. These are very stiff cables due to the weight of the cover plus the use of an acceptable sling material and thus make remote manipulation difficult. This problem was avoided by using chains instead of cable on the sling provided for the SEFOR plant. In addition, sloping guide brackets for the lift sling handle plate were provided to further facilitate remote grappling operations. 


\subsubsection{Master-Slave Manipulator}

The master-slave manipulator is located above the fuel inspection window. It has been located to one side of the window to give the operator clear view while using it and thus best serve the work stations. Loads to 16 pounds have successfully been lifted off axis by the manipulator load hook attachment. One hazard brought' to light was the lack of positive engagement inherent in the balldetent design of the various slave hand tong accessories. Tong fingers could easily be pulled loose while engaging fuel and other items. As a result of the test trials, a special tong end configuration was designed and bolted to the slave hand.

\subsubsection{Mirrors}

A flat surface mirror on a portable stand was provided for in-vessel viewing during preliminary mockup testing. In addition, two circular convex mirrors were procured and initially set up in the southeast and southwest corners (plant directions) of the cell to determine both the overall cell view and the view into the vessel from the work window. These mirrors proved effective and were used throughout the remainder of the mockup program for more detailed study. The primary advantage of convex mirrors is the much greater field of view. Even though the peripheral view is distorted, the net effect of the convex mirror is to aid operator orientation. The limited central view distortion enables close coordination of remote task motions, $i . e$. within the reactor. 


\subsubsection{Cell Lights}

In-cell illumination for the plant cell is by means of mercury vapor lamps to take advantage of long bulb life, illumination efficiency, and nearly monochromatic light necessary to avoid color fringing effects in thick glass windows. The initial lamp concept applied in the dry mockup was to place "flood" type lamps around the cell periphery at an elevation of 10 feet above the cell floor. In this arrangement near-floor illumination was very adequate using eight 400 watt lamps. Mockup work demonstrated that crowded cell conditions could be partially alleviated by placing all lamps on the cell ceiling so that fixture hardware would not restrict crane load block coverage.

Most mockup work was conducted with this latter arrangement. With the lights mounted at the cell ceiling, it was necessary to use "spot" type bulbs to direct as much illumination as possible at the cell floor regions. It was also necessary to add four 400 watt "spot" lamps on the bridge crane structure to provide supplemental illumination directly below the bridge crane. The eight 400 watt spot lamps on the ceiling resulted in illumination at the cell floor region of 50 foot-candles. Addition of the crane lamps results in doubling this to 100 foot-candles directly below the crane hoist.

\subsubsection{Man Access System (See Figures 3-1 and 3-2)}

Contact maintenance as well as preparation for reactor head removal and preparation for reactor start-up will require in-cell access routinely by two suited operators. The entry concept for SEFOR involves an entry panel bolted to the in-cell steel liner. This pane1, nominally 5 feet wide and 8 feet high houses two vinyl sealed fabric suits, four glove ports, two windows, and an emergency oval hatch. The two suits, when not in use, are attached at the necks to their respective helmet ports and are entered or exited by removal of a set of double helmets, the operator making suit ingress or egress via the enlarged 
neck of the suft: Following suit entry an assistant places a breathing air mask on the wearer and relocks the double helmet closure on the neck port. At this time, the suited operator may disengage himself from the wall panel, and the outer part of of the double helmet assembly remains attached to the entry panel as a closure, while the inner helmet becomes a part of the gas tight suit. Detachable gloves and boots make up the balance of the suit torso. Breathing and cooling air supply and exhaust as well as voice communication are carried by trail hoses and cable which attach at an in-cell wall manifold and at a rear panel on the suit. Cooling air is distributed to the extremities via tubes inside the suit while breathing air is supplied to the mask. Each man carries a five minute emergency air supply in a tank which is automatically available to the face mask upon loss of hose air.

The entry system was chosen as a means of eliminating a transfer lock and the attendent contamination control necessary during use. In this case, the suit assembly remains in the cell. Emergency entry with a face mask system only, is provided for by a crawl-through marine hatch at the bottom of the entry pane1. This hatch is to also serve as an emergency exit port.

Inittal suit work in an air atmosphere was conducted to gain operator experience and to evaluate planned emergency procedures. Tests conducted in the dry phases were: duration of the emergency air supply following loss of central station compressor, and following loss of breathing air hoses; time to rescue an unconscious suited operator from the cell, general use situations and life support equipment characteristics.

Very early it was apparent that the original suit helmets, made of opaque vinylized suit fabric with a small view window of clear vinyl, would not be satisfactory. This design was the vendors standard arrangement and was 
designed to fasten with an elastic band around the wearer's face mask. Its application to the double helmet assembly required for SEFOR was found very awkward in use. A new inner or suit helmet, consisting entirely of 40-mil clear vinyl and not requiring attachment to the wearer's face mask was obtained and is the style being supplied to the SEFOR plant.

One of the most sensitive portions of the suit design is the fit between the various interlocking neck rings which must connect and disconnect in various combinations of rotation during use. Sealing is accomplished by four elastomeric " $O$ " rings which can be simultaneously leak tested when the suit and helmets are locked at the entry panel port. From various tests it was concluded that undercutting of the " $O$ " ring grooves and a change in " 0 " ring sizes would hold the rings captive and prevent gas leakage due to insufficient compression in the initial design. Prior to undercutting the " 0 " ring grooves, exposed rings frequently dropped out during use in the cell. To give the operator greater leverage in manually rotating a bayonet engagment required during docking and undocking, handles provided were altered. Earphones of the ear plug type were replaced with mask mounted speakers as the original plug type would not stay securely fixed in the ear. Attachment of boots and gloves by the slip fit of a truncated cone insert as originally provided by the suit vendor was not adequate. Plant equipment will employ a more positive attachment using twist lock engagement and " $O$ " ring seal. Internal suit harnesses used to support the emergency air bottle and rear suit air pressure control manifold were not felt to be entirely satisfactory as originally supplied. This strap assembly was modified to include standard auto seat belt hardward which could more easily be adjusted and would not slip after buckling up. During the course of suit use it was found that various metal stop pins in the multiple neck ring assembly were becoming deformed through use. These were replaced with hard rubber bumpers which appear to be a satisfactory solution. 
A normal entry procedure involving a routine check list of file support equipment functioning was found to require 15 to 20 minutes. A rapid cell exit via the enlarged neck port could be accomplished within two minutes if necessary while a more normal exit requires about 5 minutes. Trial emergency rescue involving retrieval of a prone suited operator was performed in less than 4 minutes. In this latter case, a third operator with face mask entered the cell via the emergency entry marine hatch and assisted one suited operator to pass the second, prone suited operator out through the marine hatch. Two people outside received the prone operator in the air zone and removed his face mask to complete the rescue sequence. With the operator's face mask regulator set for a "demand" basis, the 5 SCF emergency air bottle life could be extended from 5 minutes to as much as 13 minutes; more than enough time to effect a normal exit sequence upon loss of air supplied by the trail hose.

\subsubsection{Perlscope}

A standard Kollmorgan model 301 thru-wall periscope with magnifications of $4 \mathrm{X}, 6 \mathrm{X}, 20 \mathrm{X}$, and $30 \mathrm{X}$ was purchased for the plant refueling cell and utilized during the cell mockup work. In this case, to maintain the cell environment, the objective lens and prismatic scanning head at the in-cell wall face was covered with a hemispherical, optically ground, radiation resistant glass cover.

Use of the periscope during mockup trials was intended to evaluate its effectiveness primarily during fuel inspection. The periscope location gave first consideration to viewing of fuel rods located in the fuel inspection station situated in the northwest corner of the cell. Periscope viewing into the open reactor during refueling was thus compromised since, at the planned location, less than half of the fuel rod positions can be observed. Refueling trials utilizing the periscope demonstrated that, with proper location, it could serve as a valuable optical tool for the operator monitoring the engagement of grapples onto fuel handles within the reactor vessel. The magnified, clear 
image with true color and depth perception exceeds in quality either viewing with window, mirror or television. Its disadvantages are fixed viewing angle from any given wail port and the restriction of keeping one's eye at the eye piece during periscope use. The plant will have the option of utilizing the periscope at any of several alternate thru-wall ports to favor refueling coverage, but at the expense of losing view coverage in the inspection station zone.

\subsubsection{Fuel Rod Dimensional Inspection Equ1pment}

The fuel rod dimensional inspection equipment is used for determining the fuel rod length, diameter, and bow, as well as for fuel rod positioning required for gamma scan inspection. The station was set-up and the transducer equipment was calibrated and adjusted per the procedures outlined in the manufacturers instruction manual. The three transducers mounted on the equipment are labeled and used as follows: " $A$ " detects fuel rod length from the slot on the lower end of the fuel rod to the underside of the ledge surface at the lower end of the extension rod. " $B$ " and " $C$ " detect lateral displacement. These may be used separately for "bow" measurements or the signals may be combined for diameter measurements. Carriage position and $0^{\circ}$ angular position are automatically recorded (along with the selected transducer $A, B, C$, or $B+C$ ) during operation of the equipment.

The entire series of tests were performed on a reference fuel rod using all the transducers and combinations of settings. The tests were performed a second time to check repeatability of the equipment and were highly successful. No modifications were required once this equipment was initially checked out. 


\title{
4.2.5 Vesse1 Head Lift Sling
}

The lift sling functioned as designed. However, upon installation of the mercury vapor lamps on the crane, it was no longer possible to elevate the sling spreader plate high enough to place the reactor head on its storage stand. Interference between the upper end of the sling and crane lamp bonnets necessitated shortening of the crane sling.

\subsubsection{General Purpose Crapple}

This grapple was tested to determine the capability for retrieving items that may be accidentally dropped or knocked to the refueling cell floor (primarily radioactive items which could not be retrieved by man entry). Effective retrieval of the following items was accomplished.

\author{
Channel Orifice \\ Vessel Head Nut \\ Fuel Rod Assembly Pin \\ Used Pin Receive Cup from \\ Disassembly Equipment \\ Closure Lid from Fuel \\ Shipping Can \\ Fuel Rod
}


Fuel Channel Orific̈e

The orifice was placed on the floor in a semi-horizontal position. The grapple was positioned and lowered to permit latch finger attachment as shown in the sketch. The grapple was locked

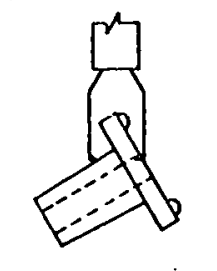
onto the orifice and a successful retrieval was accomplished. The orifice was checked while suspended from the grapple and found to be securely held. It was, however, scratched by the sharp corners of the grapple fingers. The est1mated scratch depth was approximately 0.005 inches.

\section{Vessel Head Nut}

A mockup vessel head nut was located on the floor to be retrieved with the grapple. Ordinarily this item would not have to be grappled, but because of its cylindrical shape it was deemed a challenging test for the grapple. The nut was positioned as in (A) for the first attempt. The grapple was

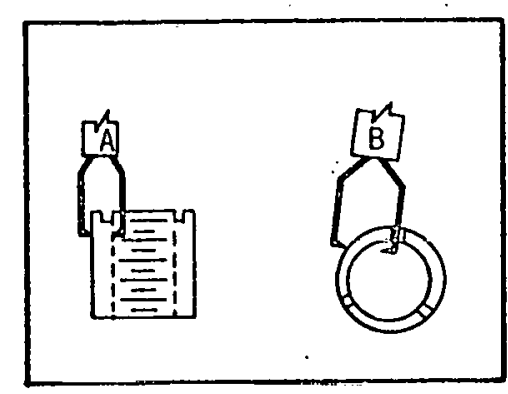
lowered into position with one finger in the threaded area and two fingers against the body. The grapple was actuated, locking the fingers, and the nut was retrieved.

The nut was then placed on the floor as in (B) permitting it to roll free. An attempt to grapple in a similar fashion as (A) was made, but the . fingers slipped free of the cylindrical surface during lifting and the nut dropped. The grapple fingers were then opened and the grapple lowered and positioned as in (B). The grapple was actuated and one finger locked in the study tensioner slot and two fingers on the body. The nut was then succesfully retrieved. 
These tests have shown that the nut can be lifted with a proper orientation of the grapple. It would have been considerably more difficult in the second test if it were not for the diamond deck floor plate which restricts the ability of cylindrical objects to roll. Again, evidence of scratching the nut surface by the grapple fingers was noted.

\section{Fuel Rod Shipping Container Lid}

The lid was placed on the floor in a horizontal attitude (see sketch). The grapple was lowered, and positioned as in (A). The locking mechanism was actuated and the lid was retrieved. The lid was again placed on the deck in essentially the same attitude. The grapple with fingers open was lowered and positioned as in (B).

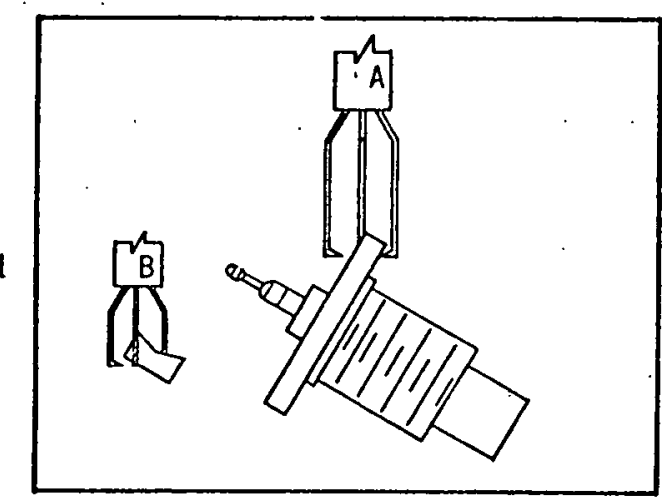
The locking mechanism was actuated and the hoist was operated to lift at slow speed. Upon reaching an angle of $75-80^{\circ}$ with the floor, the lid slipped through the grapple fingers and came to a rest in a vertical position. In this.position, either the general purpose grapple, half-ton hoist grapple, or fuel rod grapple could be utilized to retrieve the lid.

\section{Fuel Rod Assembly Pin}

Some difficulty was encountered in attempting to retrieve the pin from the floor since the grapple hook design does not enable a clamping action on an object of that size and shape. Successful retrieval was accomplished, however, by grappling the pin so that it was "cradled" between two hook figers on one side and one hook finger on the opposite side. 
Cup for Receiving a Used Pin from the Disassembly Equipment

The cup was easily grappled in both the (A) and (B) position by positioning the grapple to have one finger in

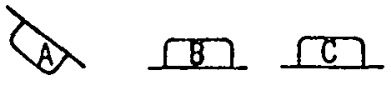
the cup and two outside. It is not possible to make a retrieval with the cup in position (C), since the grapple is not designed for this large an object. The cup has since been chained to the disassembly equipment. This has eliminated it from the list of items to be retrieved in the event of accidental displacement, since the master-slave manipulator can reach the anchored end of the chain and thus retrieve it without the aid of the grapple.

\section{Fuel Rod}

Different attempts were made at retrieving a fuel rod from the floor before a method was

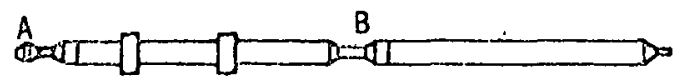
established for raising the fuel rod to a near vertical orientation and thus enable conventional grappling at the fuel rod handle. The method established for successful retrieval requires the combined use of the general purpose grapple and the master-slave manipulator (MSM). The rod must be transported to the sphere of operation of the MSM by grappling and lifting at the rod center of gravity. If this region is not accessible the rod should be grappled wherever possible, raising that end a few inches, and them moved to an area where the center of gravity is accessible. The rod must then be placed on the floor, re-grappled toward the top end, and raised to a 30 to 40 degree angle from the floor. [Severe gouging of the fuel rod and damage to the grapple fingers would occur if the rod is raised to an angle greater than $40^{\circ}$ from horizontal. This is due to large movement arm effect of the 9 foot long fuel rod relative to the short length and firm grasp of the grapple fingers.] At this time the MSM tongs should be oriented outward into the cell with the open end slightly upward since the grappling force of the MSM is not adequate to hold the rod. The grapple is released from the rod when the rod is thus 
cradled in the MSM tongs and the rod weight is taken by the MSM. When the grapple is moved aside, the rod should be raised to an angle in excess of $60^{\circ}$ at which time the grapple can be locked onto the "head" of the handle thereby completing the recovery. It is advisable to rest the bottom end of the fuel rod against some obstruction on the floor to prevent rod slipping while the MSM is in use. Also, depending on the rod position and point of attachment of the MSM, it may be necessary to progress in a stepwise fashion from the $30^{\circ}$ to $60^{\circ}$ using the grapple and MSM successively to "inch" the rod to the near-vertical orientation. It should again be noted that the grapple would be damaged by allowing the rod to pivot in its grasp at angular positions greater than $40^{\circ}$ from horizontal.

\subsubsection{Argon Recirculation System}

The plant refueling cell atmosphere of high purity argon will be maintained by a closed cooling loop circulating 2000 pounds of argon per hour to remove a maximum heat load of $50,000 \mathrm{Btu}$ per hour from the ce11 and an additional $25,000 \mathrm{Btu}$ per hour from the recirculation blower. A parallel purification loop will take $10 \%$ of the gas flow from the cooling loop and pass it through a NaK Bubbler to remove impurities other than nitrogen. Cell pressure control is partially accomplished by the purification loop which includes a 10 psig compressor and reservoir tank. Variations in storage pressure within the reservoir of the purification loop will make possible hold-up and salvage of excess gas during periods when the in-cell gas temperature increases. While the plant cell pressure control will be automatically held between high and low pressure limits, the mockup gas system was less complete and required manual adjustment. Gas flow was established in the mockup simulating plant conditions; air was used during dry phase tests, and argon was used during wet phase tests. 
It was found that four 8-inch diameter gas inlet ducts near the cell floor and four 8-inch diameter gas outlet ducts at the cell ceiling resulted in excessive gas velocities and noise at plant flow rates. These ducts for the mockup and for the plant design were modified to 16-inch diameter. In addition, adjustable flat plate diffusers were installed at the inlet openings to enable balancing of gas flow rates and to control flow over the open reactor and fuel storage areas which could deflect the cable sling grapples. These diffusers were made adjustable to enable balancing of the gas flow rates across all four inlets. Reduction in gas flow induced noise level is important since during plant operation it is desired to broadcast outside the cell the operating sounds from mechanical equipment inside the cell. This will enable operators to monitor for potential malfunction of in-cell equipment.

\subsubsection{Instrumented Fuel Assembiy}

During installation of the prototype instrumented fuel assembly into the vesse1 mockup, balance, adjustments and clearances were checked out.

A potential problem was observed in the action of the guide slot of the electrical connector. Under extreme conditions the alignment was not close enough to allow engagement of the flange dowels. An additional guide block was provided on the reactor model instrumented fuel assemblies to correct this condition.

It was observed that replacement of the three separate handling lugs with one movable lug would make the lifting more versatile in maintaining alignment by the weight balance. This change was made for reactor operation. 
The voltage was found to be low for actuating the solenoid grapplies on the lifting fixture. This problem was solved by adding a voltage boost circuit in the electrical panel.

During the trail insertion an intereference between the lifting fixture frame and the vessel mounted electrical connector flange was observed. The lifting fixture frame was modified to provide necessary clearance for reactor insertion:

The instrumented fuel assembly, clamped in the transport fixture, was "bagged" into the refueling cell and placed in the wall brackets provided for it. It was found that ithe wing nut clamp fasteners which required a $90^{\circ}$ turn to unlock the instrumented fuel assembly in the transport fixture were a potential problem for reactor operation. The design was changed and pull pins have been used on the transport fixtures going to the reactor site.

\subsubsection{Closed Circuit Television}

The TV proved to be a valuable tool in monitoring a wide range of remote handling tasks. As stated in the discussion of "Equipment Location Trials", wall mounting of the TV camera appeared to be the most convenient arrangement. A remotely driven wall-mounted boom was provided on the north wall of the cell. However, provisions were made to use the in-cell bridge crane for remote relocation at either the wall boom or on a floor mounted tripod. The $180^{\circ}$ horizontal swing capability of the 5 foot boom results in a wide range of view angles from a camera height approximately 20 feet above the cell floor. A 10 to 1 zoom lens system overcomes the problem of viewing distance. Pigures 4-2 and 4-3 show typical views obtained with the television system. 


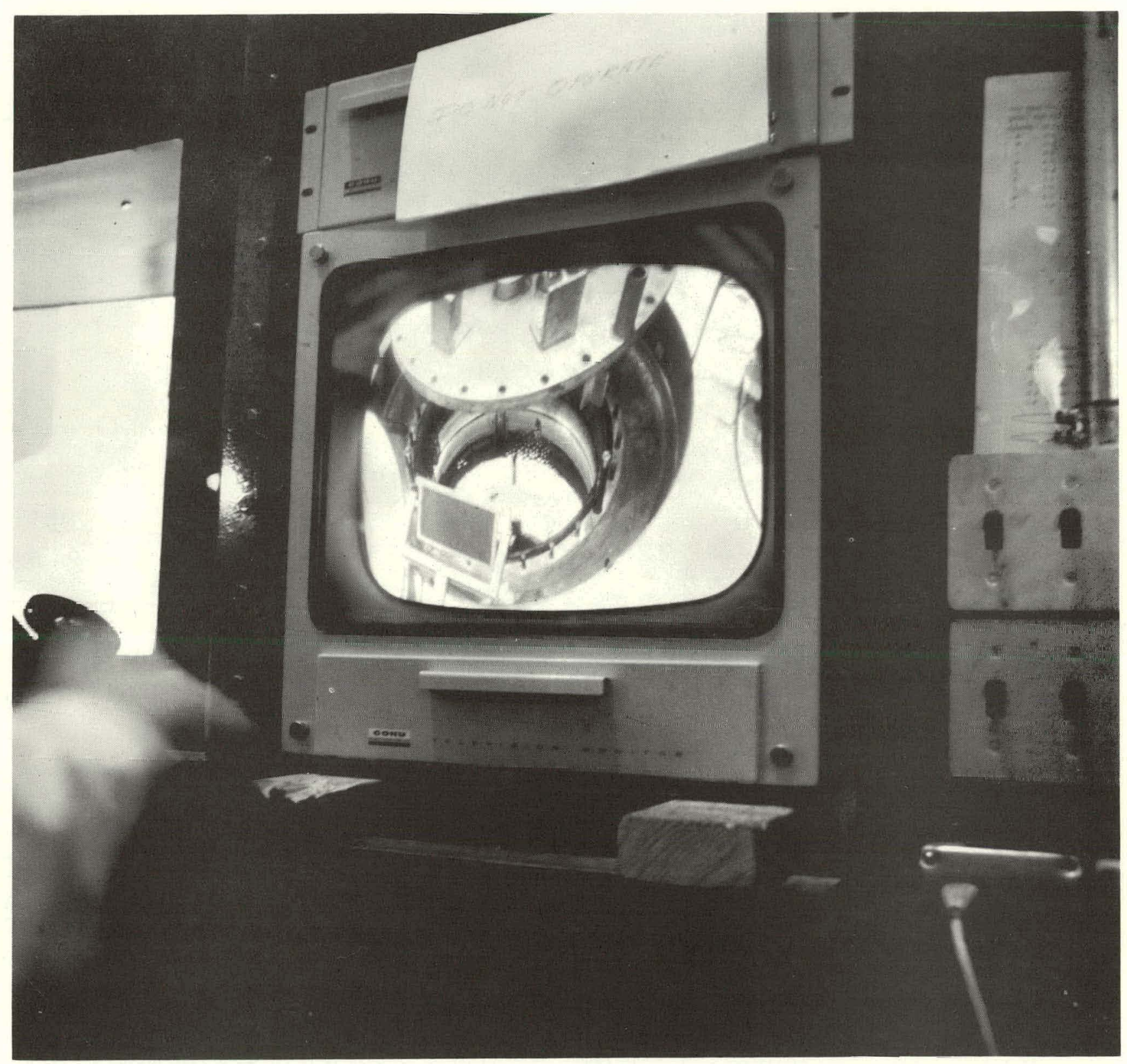

FIGURE 4-2. INTERIOR OF MOCKUP VESSEL ASSEMBLY THROUGH TELEVISION 
GEAP-5701

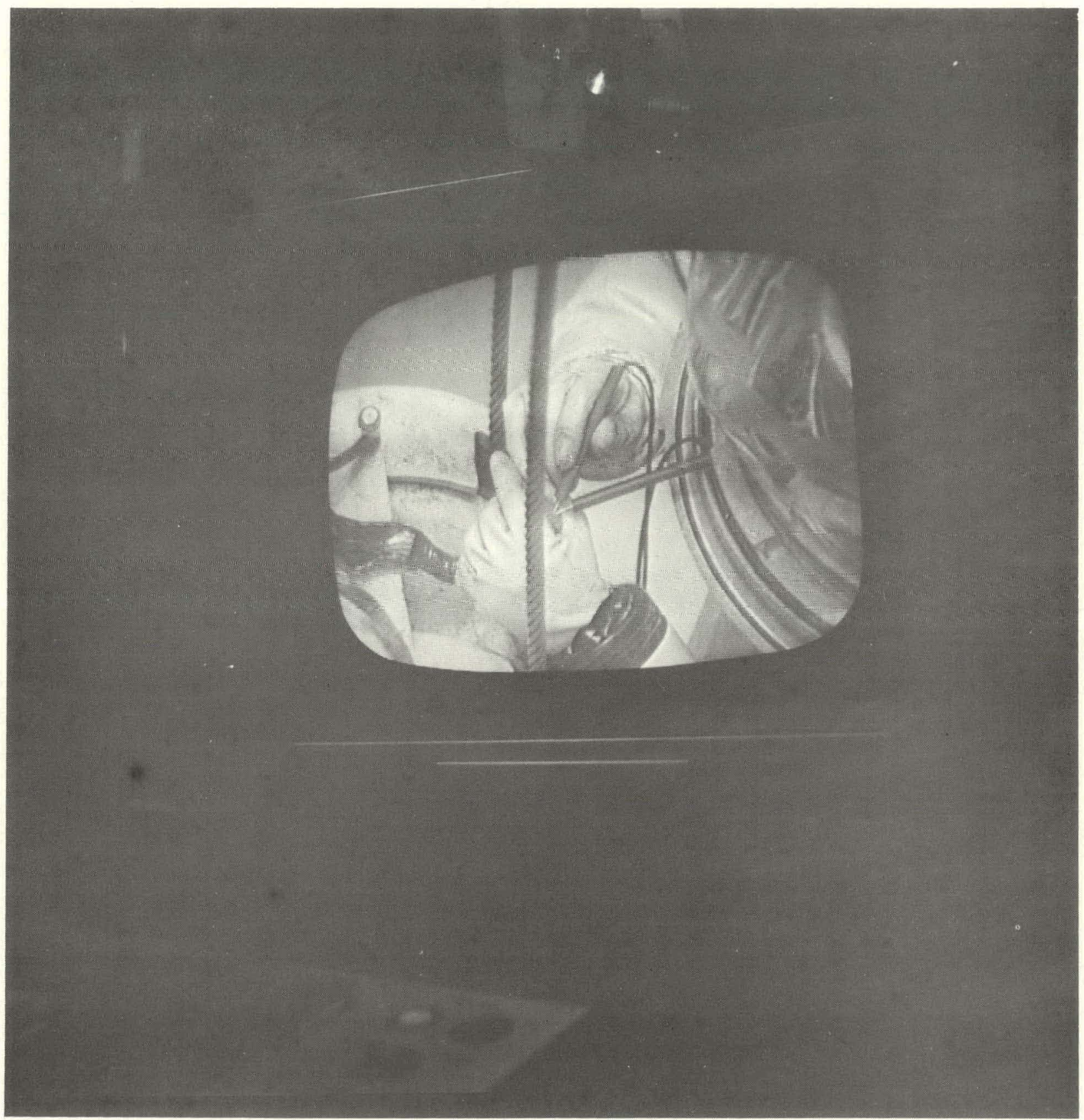

FIGURE 4-3. CRANE CABLE REPAIR WORK AS

SEEN VIA TELEVISION 
The initial camera tilt. drive capability of $90^{\circ}$ was inadequate. An interim design for $180^{\circ}$ tilt using the original drive case required replacement with a different pan-tilt drive since the motor drive was not strong enough to manage a full $180^{\circ}$ tilt. Mounting of the lifting bale on the camera assembly was moved to the base of the pan-tilt case so that the grapple handle would be vertical regardless of camera tilt.

The boom drive required modification to correct misalignment of its drive motor and to prevent stalling. Limit switches on the drive were also found advisable to prevent driving the camera into the cell wall.

In trying to provide for the maximum detailed image on the monitor it was found that yellow was the preferred color. Yellow stands out well and yet reflects adequate light as compared with a dark color. For TV viewing, differences in degree of reflectivity work best since most strong colors are too dark and detail is lost within the dark image on the monitor. The only problem with yellow is that it provides no clear distinguishing characteristic from one piece of equipment to another. This objection would be overridden by outlining the items in black. In general, a floor illumination level of 80 foot-candles proved adequate for through-window and TV viewing.

\subsubsection{Multi-ton Grapple}

The grapple functioned extremely well and required only an external dotted line-solid line marking to indicate the position of the receiver with respect to the grapple handle and give to the operator additional information pertaining to the locked or unlocked position. 


\subsubsection{Half-ton Hoist}

The grapple solenoid did not function properly as originally installed. This was due to the combination of the high current requirement of the "puilin" coil and the resistance of the approximately $200 \mathrm{ft}$ long electrical leads between the power supply and the grapple. This deficiency was corrected before test operations began by the addition of a voltage boost circuit which is used to inft1ally open the grapple. Following this initial modification, the hallfton hoist and grapple functioned flawlessly; and, during a period when the main grapple system was inoperative due to a faulty power cable, it was used in place of the fuel rod grapple to remove and reload fuel rods. It was considered advantageous to have the grapple nose extended to facilitate viewing of the fuel rod handles when grappling in the vessel. To further enhance the capabilities of this grapple, a removable collar weight was included to provide the push necessary to actuate the tightener rods in the core.

\subsubsection{Fuel Storage Tanks}

Tests conducted with a dummy channel and fuel rod ends revealed the marginal side wall clearance making operations with the fuel grapple in the peripheral storage locations questionable. This outer ring of fuel rod storage locations, however, can be readily reached with the half-ton hoist grapple.

\subsubsection{Grapple Storage Racks}

The racks required only minor adjustments of the connector operating mechanism. Test work with this equipment revealed the possibility of connector mechanism damage if routine operational procedures were not followed when making the attachment with the multi-ton grapple. Spacers were added which raise the storage position of the fuel grapple and general purpose grapple, thus eliminating this damage potential. 


\subsubsection{Fuel Rod Assembly, Disassembly and Canning Equipment}

The disassembly station required minor adjustments to align the connecting pin of the rod with the pin extractor and crimper. The support for the torque tool required an offset saddle to provide for grapple clearance and yet enable proper alignment of the torque tool with the lid of the fuel transfer container. These modifications were made and the modified equipment was available for wet phase testing.

\subsubsection{Mirrors}

Fuel handling tests during the dry phase led to a decision to assembly a group of 3 mirrors on a remotely operated pan and tilt drive which in turn was mounted on a floor pedastal adjacent to the reactor head for use by operators standing at the reactor service window. This assembly included two circular convex mirrors and one flat mirror. One convex mirror provides an orientation view of the entire reactor interior (above sodium leve1). A second convex mirror permits the operator to visually monitor the upper cell regions to avoid conflicts between bridge crane wire ropes and other cell equipment during transport. The flat mirror is oriented to provide the operator with a undistorted view of grappling sequences within the reactor vessel. All three of the views described above are provided simultaneously to an operator viewing through the window. The design which evolved for the plant stemmed directly from dry mockup trials though all of the final equipment was not available in time for proof testing during the mockup test period. 


\subsection{WET MOCKUP TESTING}

This period of refueling cell operation duplicated all but the nuclear environment typical of the plant. The cell argon atmosphere purity was brought to the plant specifications of less than $10 \mathrm{ppm}$ of $\mathrm{O}_{2}$ and $\mathrm{H}_{2} \mathrm{O}$, and less than $5 \%$ by volume of nitrogen. This was accomplished by systematic purging and recirculation cycles of approximately 30 minutes each for a period of 12 to 14 hours followed by operation of the argon purifier loop to bring $\mathrm{O}_{2}$ and $\mathrm{H}_{2} \mathrm{O}$ levels from near $1000 \mathrm{ppm}$ to less than $10 \mathrm{ppm}$. The following paragraphs summarize the results of test conducted under these environmental conditions.

\subsubsection{Instrumented Fuel Assemb1y (IFA)}

At the onset of the wet testing phase information was required on the operation of the prototype IFA thermocouple and electrical connector performance. Therefore, during and following the period when the cell atmosphere was being changed over to argon, the mockup vessel was filled with sodium to a level just below the IFA connector mating joint, the sodium temperature raised to $1000^{\circ} \mathrm{F}$ and held for approximately five days while recording the thermocouple response, and the thermocouple lead tube was monitored for connector leakage. The test results showed that the connector and instrumented fuel assembly operated satisfactorily in sodium at $1000^{\circ} \mathrm{F}$ (normal exit reactor sodium temperature is $\left.820^{\circ} \mathrm{F}\right)$. Figure $4-4$ shows the IFA being moved in the cell mockup.

\subsubsection{Sodium Sampling}

The thru-head sodium sampling equipment was bagged into the cell and placed, along with its shipping cask, in the canning facility of the disassembly station. One of the head nozzle flanges was unbolted during a suited man entry into the cell; then the flange was remotely removed. The extension for the sampler was grappled and the connection to the sampler made. The unit was lowered through the nozzel into the vessel and removed five minutes later with 


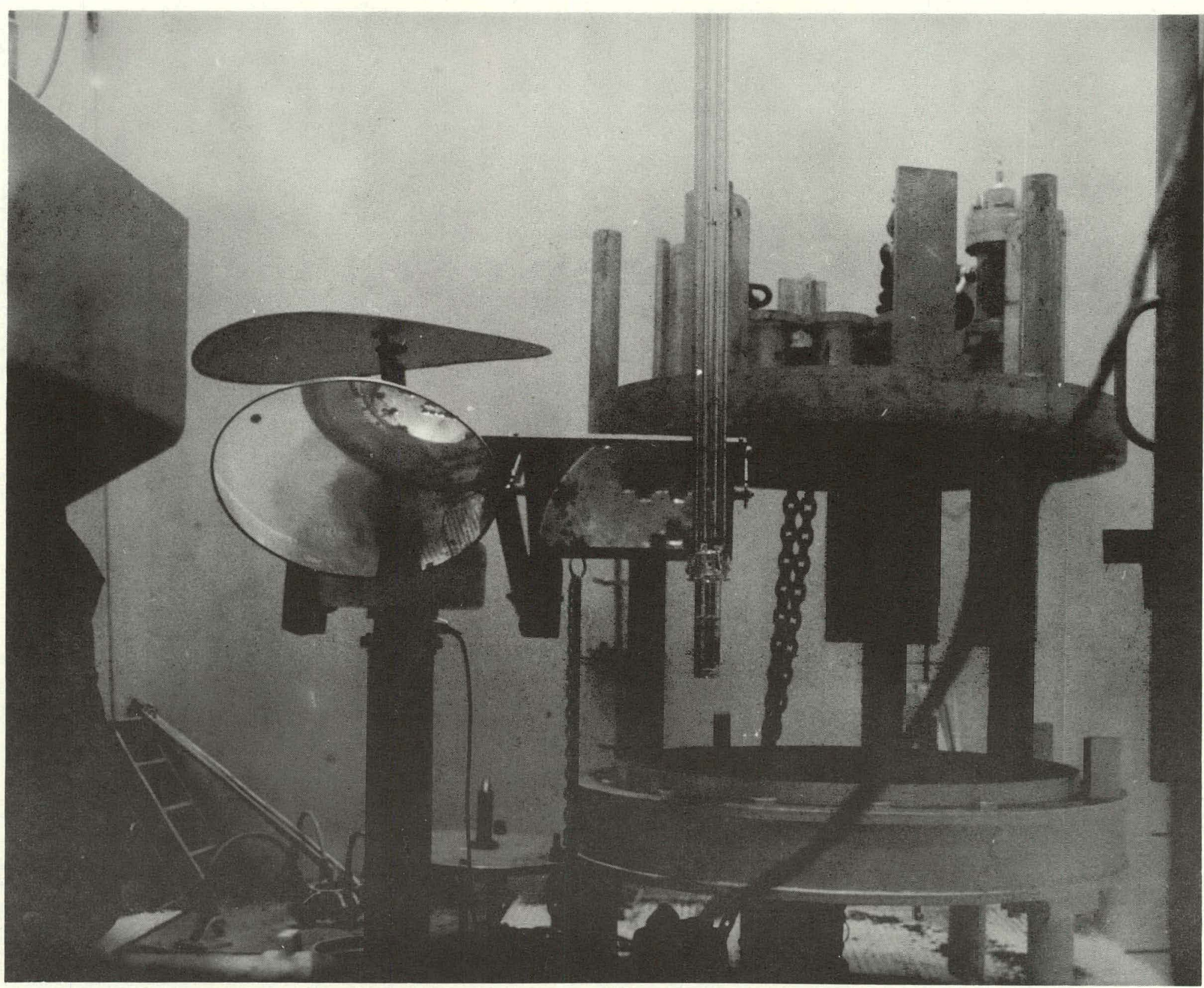

9
Mr
P
1
Un
0

FIGURE 4-4. INSTRUMENTED FUEL ASSEMBLY IN TRANEIT 
all sample cups full of sodium. The sampler was placed and sealed in the shipping container. The combination of the "drain free" design and lack of "sodium-wetting" resulted in the sample cup holder being clean and dry, thus causing no drippage problem. Figure 4-5 shows the sodium samples being withdrawn from the mockup vessel.

\subsubsection{Vertical Transfer}

The sodium sample was allowed to set overnight and freeze to avoid spillage during handling through the vertical transfer system. A plastic tube was fitted to the shroud below the transfer valve and purged to an argon atmosphere. Using the bridge crane and grapple system, the veritical transfer shield plug was removed and the sampler container grappled and brought to a position over the transfer valve. The valve was opened and the sampler container lowered. After releasing, the grapple was withdrawn, the valve closed, and the shield plug replaced. No problems were encountered in performing this vertical transfer operation. However, this did not simulate the radiation shielding that may be required for an irradiated fuel transfer.

\subsubsection{Thru-Head Refueling}

A man entry was made to unbolt the upper flange of the thru-head refueling nozzle. The task was performed utilizing the torque tool stored on the fuel rod disassembly station. The men exited from the cell and the flange was remotely removed with the fuel rod grapple. The grapple was attached to the tightener rod and it was raised the necessary four inches to unlock the fuel rods. The forces applied during this operation were as follows: 130 pounds to start moving the tightener rod, 100 to 110 pounds while raising the rod approximately 4 inches, and 30 pounds final force indicating completion of the unlocking action. 


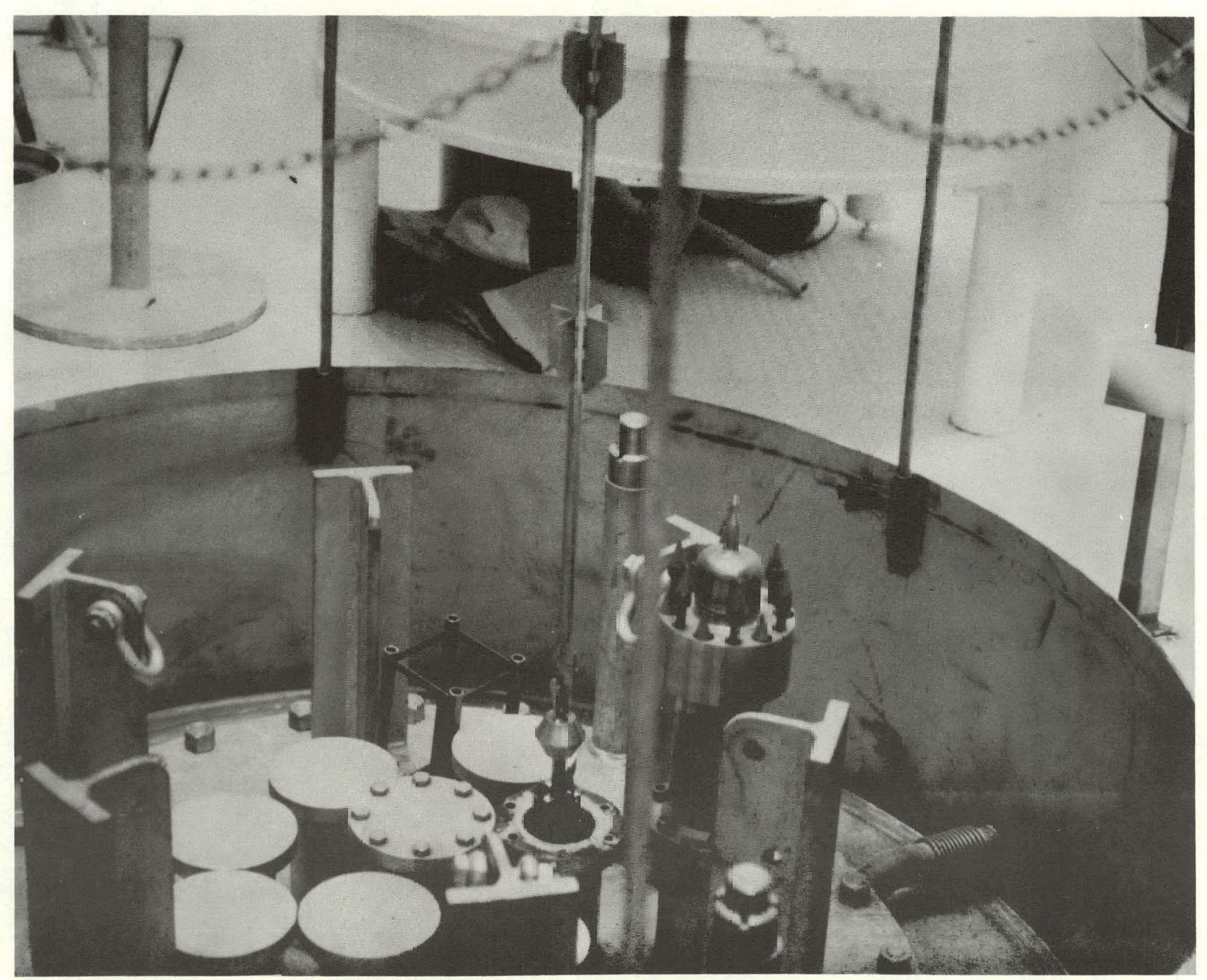


The predicted initial force required to unlock the through-head tightener rod was 110 pounds ( 80 pounds friction plus 30 pounds weight). It should be noted that the friction force involved in through-head fuel and tightener rod movements is about 30 percent larger than that associated with head-off fuel handling. This is due to added weight and additional bearing surfaces which contact the rods in the through-head positions. The fuel rod was grappled and lifted out of the vessel. The fuel rod began moving with an applied force of 50 pounds after which a withdrawal load of 30-35 pounds was observed. The rod appeared to be wetted judging from thru-window observations. Examination via the periscope a short time later revealed a droplet covered surface (Figure 4-6). This transition from a wetted appearance progressed to larger and larger droplets until the freezing temperature was reached. After examination in the inspection station, the fuel rod was reinserted and the tightener rod pushed down. The tightener rod required 55 to 80 pounds of force to push it back into the tight mode. Several such satisfactory thru-head refueling operations were performed.

\subsubsection{Fuel Inspection}

The fuel rod dimensional inspection equipment was used to obtain the following data on a reference fuel rod prior to thru-head fuel handling operations; reference diameter check, diameter spiral trace, diameter versus length trace at $0^{\circ}$ angle, bow spiral trace, and bow at a fixed angular position (angle of maximum bow). This data compared very well with that obtained during dry mockup testing. As each of the two thru-head refueling rods were removed they were placed in the inspection station and subjected to the preceding checks. These tests were performed to determine the effect of the sodium coating even though the plant operation is based on cleaning the rods prior to inspection.*

\footnotetext{
* Fuel Rod Leak Check and Cleaning Equipment was not available for use in the mockup testing.
} 


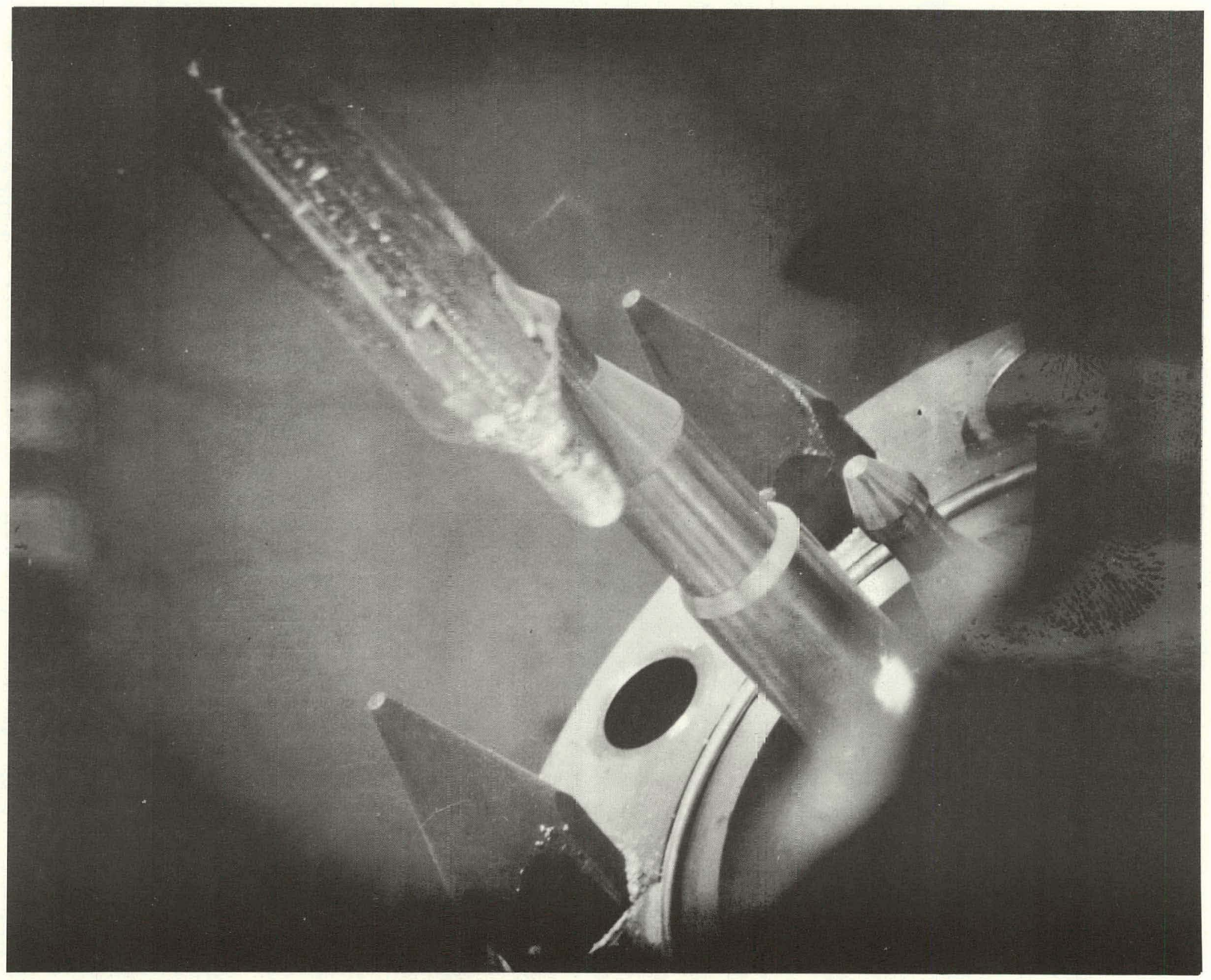


The chart traces showed the effect of the sodium globules on the rod surface. The "hash" caused by the globules had a maximum amplitude of several thousandths of an inch. Following their inspection the rods were replaced in the vessel and a man entry was made the following day for the specific purpose of wiping the rods as they were being withdrawn prior to reexamination in the fuel inspection station (Figure 4-7). This reduced the maximum amplitude of the "hash" to a few ten-thousandths of an inch. Thus, either an "unwiped" or "wiped" rod can be used to determine a diameter change of 10 mils, which is the limit for re-inserting the rod into the core.

\subsubsection{Fuel Rod Disassembly, Canning and Re-Assembly}

The two sodium-coated fuel rods discussed above were placed in the disassembly station, the pins were ejected and the extension rods were removed. A lifting force of 150 pounds was required to separate the extension rod from the fuel rod. With this applied load, the sodium bond slowly sheared and the extension separated from the fuel rod. This demonstrated that the disassembly operation can be performed without first removing the sodium although cleaning is intended prior to disassembly or assembly operations at the SEFOR site.* The fuel rods were then transferred to the shipping can mounted in the disassembly station, and the can was sealed. Vertical fuel transfer was not attempted at this time since successful operation had been demonstrated with the sodium sampler.

Fuel Rod Leak Check and Cleaning Equipment was not available for use in the mockup testing. 


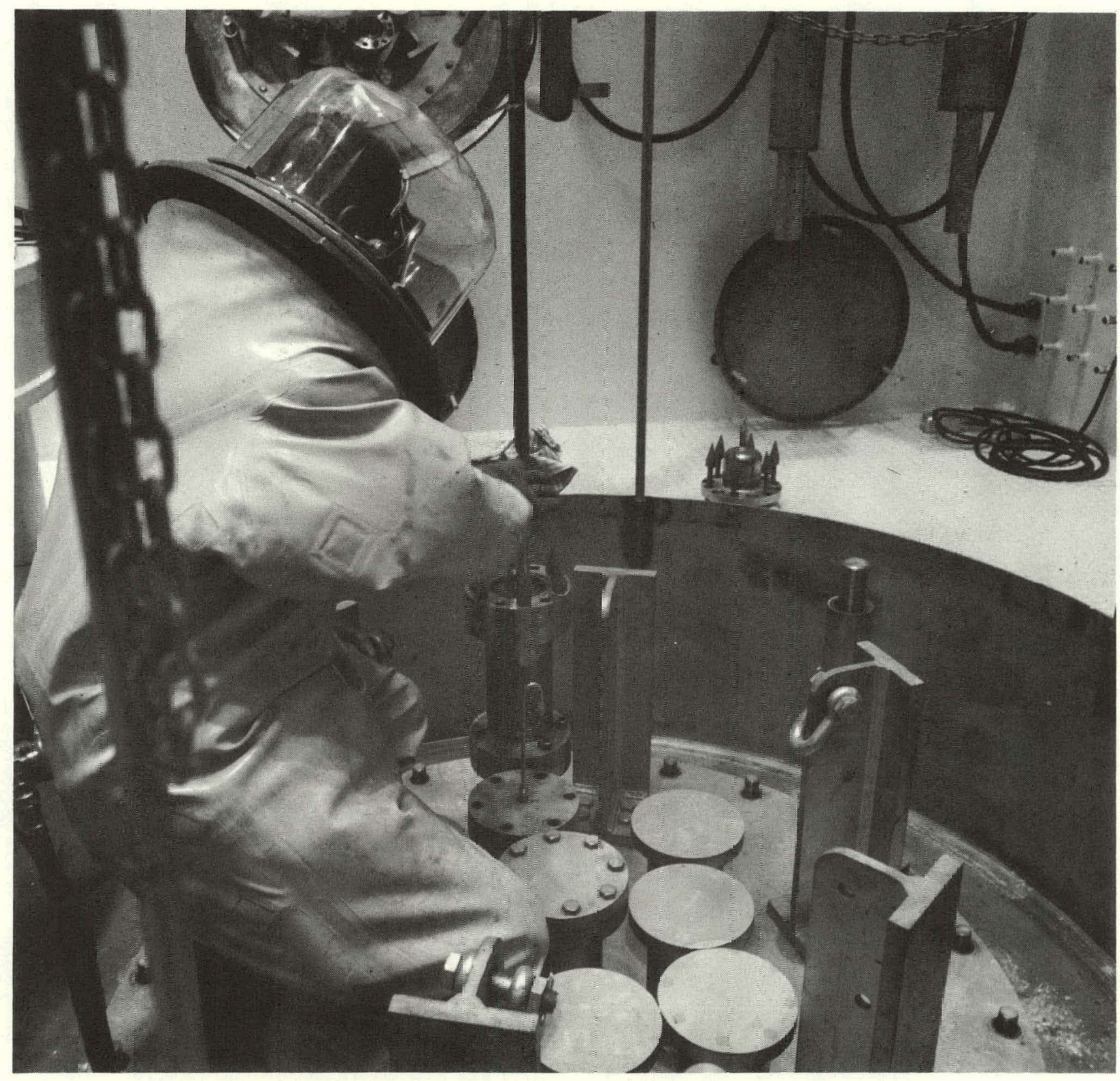


The two thru-head refueling rods were reassembled. Each of the rods had frozen sodium and sodium oxide covering the mating parts. Therefore, considerable difficulty was encountered in trying to make the assembly due to the interference of the surface coating. Repeated application of the 100 pound negative load capability of the fuel grapple provided the necessary alignment and thus enabled insertion of the connecting pin. It was noted that during installation of the connecting pin that the crimper had a tendency to hang up and not retract. This was due to the combination of the sodium-coated parts and crimper tool being driven by a single acting cylinder with a spring return. To aleviate this problem, a double-acting cylinder was installed prior to shipment to SEFOR.

\subsubsection{Man Access System}

The most extensive experience with the man access system occurred during the environmental test phase of the program. Many of the desired modifications determined during the dry test program had to be postponed until the conclusion of the cell mockup tests in order not to delay the test schedule. Suited entry into the inert atmosphere of the refueling cell mockup was a frequent requirement to service other test equipment within the cell and which could not conveniently be removed for servicing in air (Figure 4-8). During this suit use further modifications considered essential for satisfactory plant use were determined. The most serious problem became that of pressure control within the suit itself. Suit ingress and egress through the enlarged neck opening requires that the torso styling be very ample to permit the operator sufficient room to properly harness and unharness himself about the waist region when still attached to the entry panel. The excessive free volume of the suit is subject to rapid volumetric changes resulting from walking, bending, or crawling during in-cell work. The automatic vacuum exhaust manifold within the suit was unable to maintain a neutral internal suit air pressure relative to the cell. Frequent over-pressure conditions resulted within the suit which 


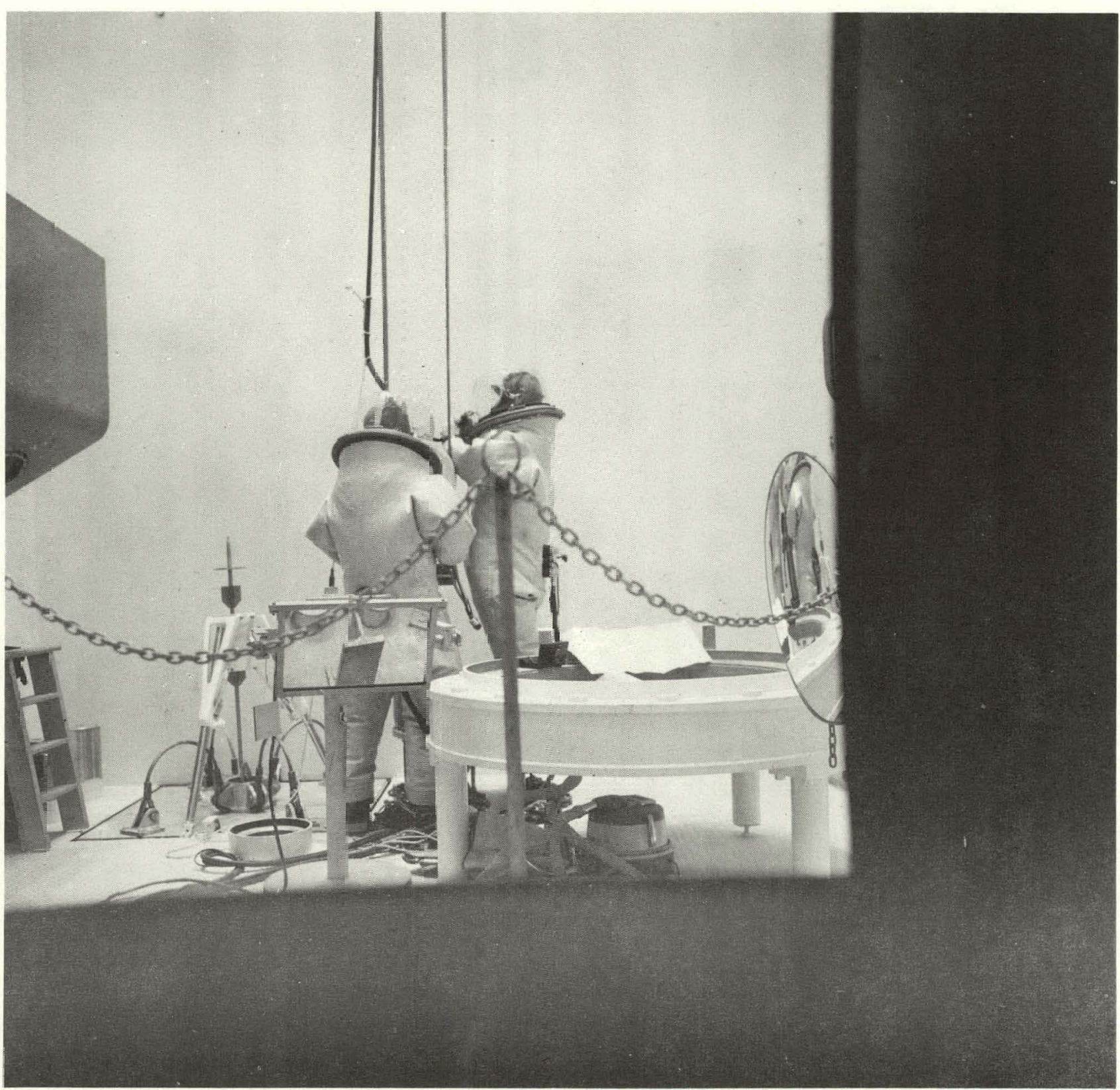


were automatically relieved by a pair of spring-loaded over-pressure relief valves direct to the cell argon atmosphere. A release of 1 SCF of air is sufficient to increase the oxygen impurity level in the argon atmosphere by $30 \mathrm{ppm}$ which is a level three times that desired. In addition, this condition resulted with the suit internal cooling air flow rate at 10 SCFM. Operator comfort is considerably improved when cooling air flow rates up to 25 SCFM can be achieved. Cooling air supplied during tests was predried to a $-12^{\circ} \mathrm{F}$ dew point at 1 atmosphere absolute pressure and to a delivery temperature at the suit hose of $50^{\circ} \mathrm{F}$.

Upon completion of the environmental test program, the suit equipment was returned to the vendor to increase both cooling air supply and exhaust capacities. A third trail hose will also be added to direct any air flowing through the over-pressure relief ports to an air zone outside the cell. Numerous other modifications have also been suggested to the vendor to increase wear resistance and reliability of the protective clothing.

Contact maintenance capability using the suit system was very encouraging. In-cell work tasks carried out included operation of gas (argon) powered hand tools and electrical continuity checking of cable connectors having as many as 48 pins. Various pieces of equipment were also bagged in and out of the cell using suited operators inside. Two suited operators were used at all times during cell entry with standby masked personnel immediately outside. No emergency rescue procedures were required during the environmental program. There was, however, frequent trouble experienced in redocking the head ring assemblies to the man access wall panel to make normal exits from the cell. It is believed that much of this re-engagement difficulty is the result of physical fatigue at the conclusion of in-cell work and that more operator experience will be needed to overcome the difficulty of docking. 
A considerable increase in cooling air flow from the 10 SCFM available during the test program to 25 SCFM should also reduce operator fatigue. Both light weight underwear and heavy cotton sweat suit-type garments were tried by suited operators. Opinion varied as to the relative merits of each. Much of the cooling is accomplished by evaporation of body moisture. This occurs most readily with thin cotton undergarments but at the expense of getting the vinylized entry suit interior dirty more quickly.

\subsubsection{Reactor Head Removal-Replacement}

Reactor head removal required man entry to remove the head bolts. This was accomplished with the use of an argon operated impact wrench in approximately 15 minutes working time. After the bolts were removed, the three chains were attached to the head clevis pins and the men made a normal cell exit. The head lifting sling was grappled with the multi-ton grapple and the chain raised to a semi-taut condition, whereupon sightings were taken through both windows to check centering of the sling. When centering was acceptable the crane was actuated on a low speed lift of six inches per minute and the head was removed, revealing a mirror finish sodium pool (Figure 4-9). The head was moved to the storage cup and lowered. The sling was lowered to the cell floor and the grapple disconnect was made.

Replacement of the head was performed in a reverse manner except that an additional operation was required. As the head was lowered toward the vessel, the rotational capability of the multi-ton grapple was used to line up the three guide legs with the guidance grooves in the vessel flange. The three holddownguide beams for the plant were not available for the test. When the guide legs engaged the slots, the head was lowered onto the flange. 


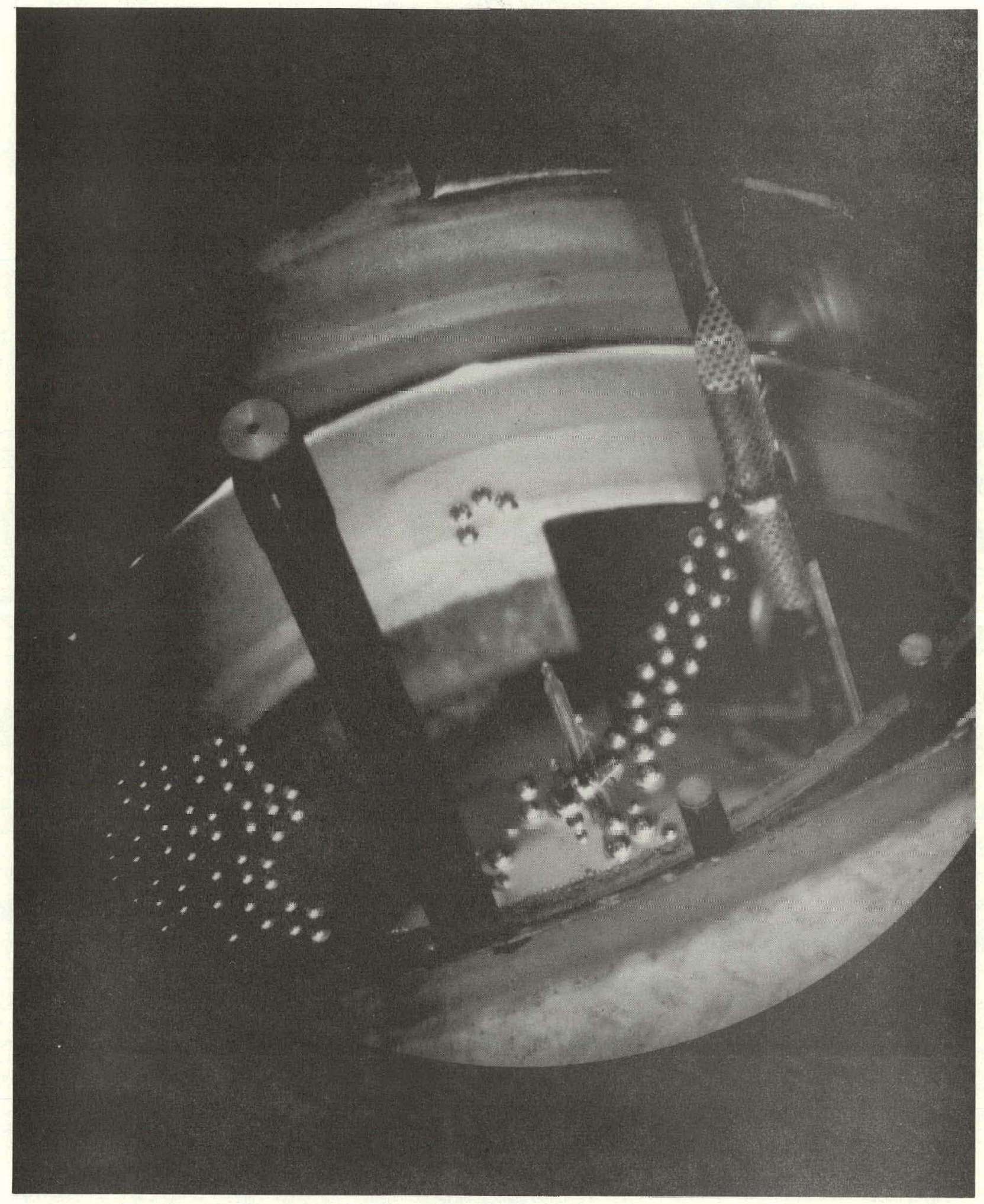

FIGURE 4-9. SODIUM SURFACE AT FUEL ROD TOPS 


\subsubsection{Periscope}

The fuel inspection periscope was mounted above and east of the north window east of the man access panel throughout both dry and wet tests. When used at the lower magnification powers of $4 \mathrm{X}$ and $6 \mathrm{X}$ the cell lighting was adequate, but the lighting was marginal at higher magnificant powers of $20 \mathrm{X}$ and $30 x$. Several crane lights planned for the plant were not available. (See dry test comments for further evaluation.) Figures 4-6 and 4-9 show typical views through the periscope.

\subsubsection{Grapples}

The multi-ton, half-ton, fuel rod and general purpose grapples all functioned well in carrying out the tasks for which they were intended. However, use of the grapples slung from the 10-ton hoist was restricted during part of the wet test operation due to trouble with the electrical cable serving these grapples. The outer sheath on this cable bunched up behind the guide rollers which direct the cable downward to follow the load block. This prevented lower level operations, such as refueling, but did not affect vessel head handling or fuel handling in the cell. The electrical cable was removed and tightly wrapped with rayon braid material, to eliminate the sheath bunching problem. A different cable guide was provided as a further improvement following the test work.

The half-ton hoist grapple was successfully used to remove and replace fuel rods in the vessel during the time when the 10 ton hoist grapple system could not be used for refueling operations. This demonstrated the backup capability of the grapple and hoist system. As mentioned in the dry mockup test description, this grapple has since been modified to enhance its capabilities by providing additional push capability and better viewing at steep view angles. 


\subsubsection{Ce11 Lights}

There was some concern during the latter part of the dry mockup work that the level of illumination would not be adequate within the upper regions of the reactor vesse1 for periscope viewing and that reflection from the liquid sodium surface would overpower the TV image. The wet test work alleviated this concern. With a proper cell argon purity the liquid sodium surface reflectivity is great enough to scatter the vertical light source and effectively illuminate the vessel interior during grappling operations. At the same time thermal currents and system vibrations are enough to keep the sodium coolant surface constantly in motion. This surface motion breaks down the mirror image effect that would otherwise be a visual distraction and a detriment to the TV image.

\subsubsection{Sodium Level Adjustment for Determining Fuel Rod Elevation in the SEFOR Vesse1}

Visual confirmation of complete fuel rod insertion is planned prior to replacement of the head on the reactor vessel following refueling operations. This will be performed by the combination of visually scanning the upper core region and taking coolant level readings, via the through-wall periscope, while adjusting the coolant level. More specifically, the coolant level will be raised, submerging all fuel rod tops, and then lowered an 1/4-inch increments, at which time the entire core region is scanned for the existence of fuel rods protruding above the sodium surface. The criteria for this test is to confirm complete fuel rod insertion within 1/2-inch accuracy. 
A test was conducted in the SEFOR mockup vessel with a special test asembly (shown in photographs, Figures 4-10 and 4-11) to evaluate the sodium level adjustment method of checking fuel rod elevations. This test assembly consisted of a sawtooth level gauge and a seven rod cluster of fuel rods with representative rod-to-rod spacing. A backing strip was placed 7/32-inch behind the level gauge to simulate the mounting arrangement in the reactor vessel. Tooth-to-tooth spacing on this gauge is 1/4-inch (1/2-inch spacing on each side with 1/4-inch offset side-to-side). As shown in Figure 4-15, four of the seven rods are of equal length and are at the same elevation as the third tooth down on the left side (this tooth not visible on Figure 4-15). One rod in the background is 1/8-inch low, the rod at the far left is 1/8-inch high and the rod in the background near the left side is 1/4-inch high (at the same elevation as the third tooth on the right side). In addition to elevation differences, the four upper end configurations were provided, representing the following different "fuel rod" types to be utilized:

1. Standard fue1 rod top for the standard (18.7\% enriched) fuel rods.

2. Double or stepped conical top for the $25 \%$ enriched fuel rods.

3. Square top for the poison rods.

4. Triangular top for all others - natural $\mathrm{UO}_{2}$ rods, practice rods, and foil holder rods.

All rod ends also included a slot milled down the side. This is used for visual angular orientation of the fuel rods. 


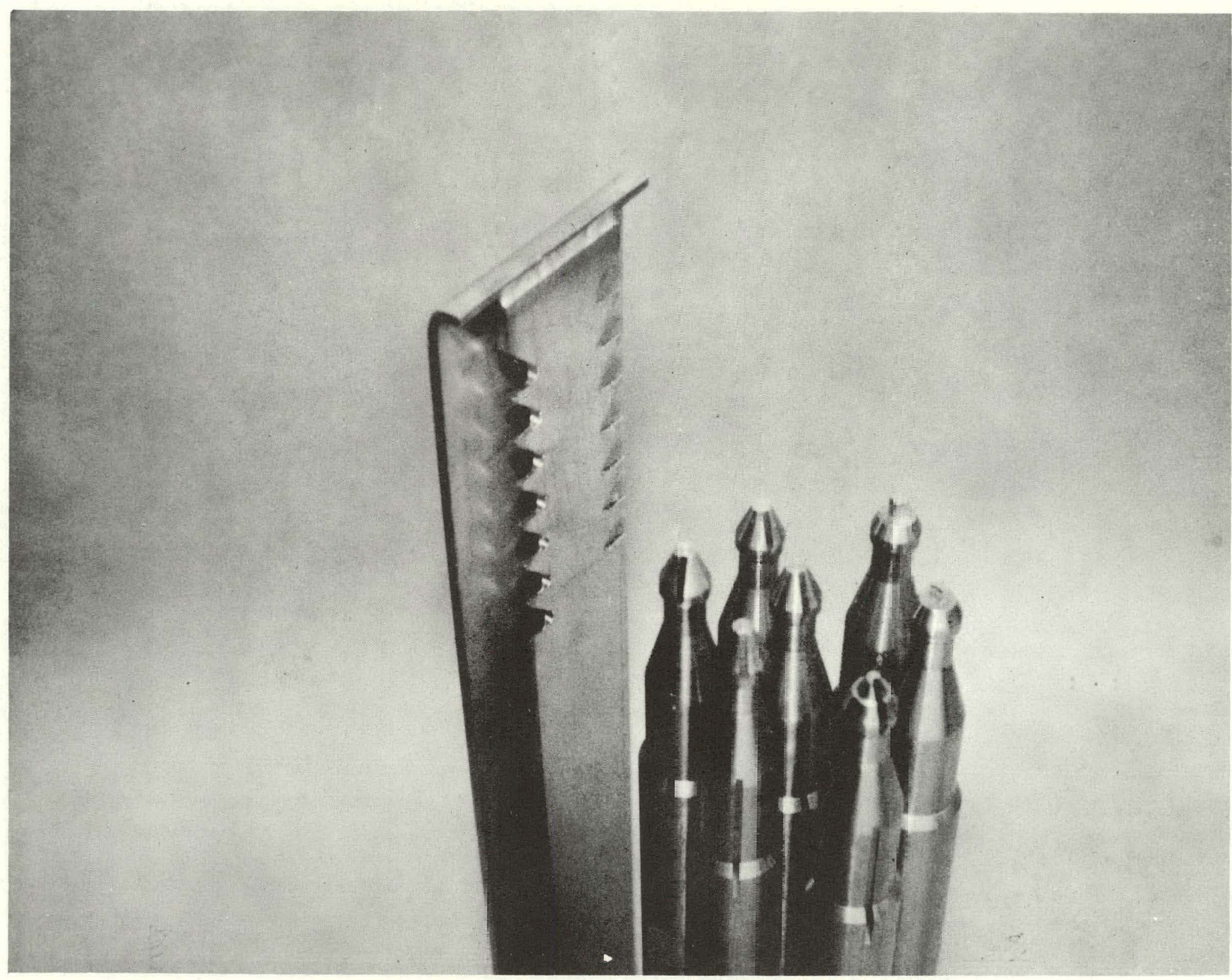

踏

FIGURE 4-10. LEVEL GAUG TEST FIYTURE - PRIOF. TO INSERTICN IN MOCKUP JESSEL 


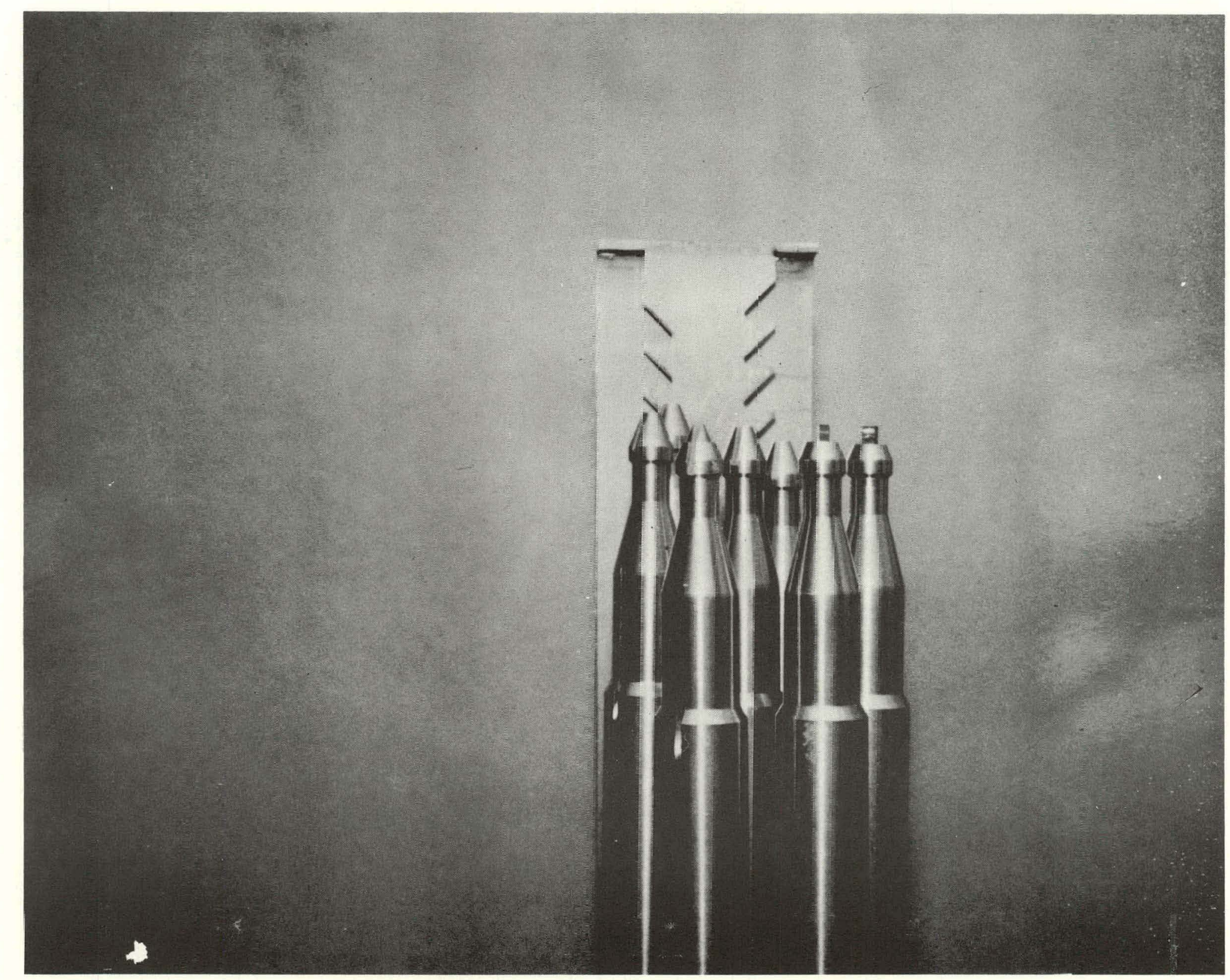


Tests were conducted by lowering the sodium to expose the fuel rod tops in a step-wise manner while observing the level indicated by the level gauge. Four time exposure photographs, taken through the periscope, are attached and discussed in the following paragraphs. These photographs, although clear enough to illustrate the effectiveness of the sodium level method for determining fuel rod positions, are not representative of the high quality image available to the operator when viewing directly with the periscope. When interpreting these photographs, one must be cognizant of the image reversal that takes place upon photographing through the periscope.

Figure 4-12 shows the $1 / 4$-inch high and $1 / 8$-inch high rods protruding through the sodium surface. The lowest tooth in view of the level gauge is the third one at the left of the photograph. After a short familiarization period, the operator can view the amount of tooth exposure and estimate the mid-point elevation between the 1/4-inch tooth spacing. The most significant contribution toward making this estimate is the meniscus height of the sodium which is slightly less than 1/8-inch. Since the upper edge of the meniscus is somewhat below the horizontal edge of the tooth, the operator is assured that the level is more than $1 / 8$-inch below this tooth. This observation is confirmed by the fact that the next tooth down is not uncovered and that the $1 / 8$-inch high fuel rod is in view.

Figure 4-13 shows the test fixture after the sodium level is lowered to expose the next four rod tops. Also shown in this photograph is the third tooth on the right which is at the same elevation as the four rods just exposed. Since the 1/8-inch meniscus is not fully developed on this tooth, the operator is assured that the level is less than $1 / 8$-inch below this point. This is confirmed by the fact that the seventh rod (1/8-inch the rest) has not come into view. 


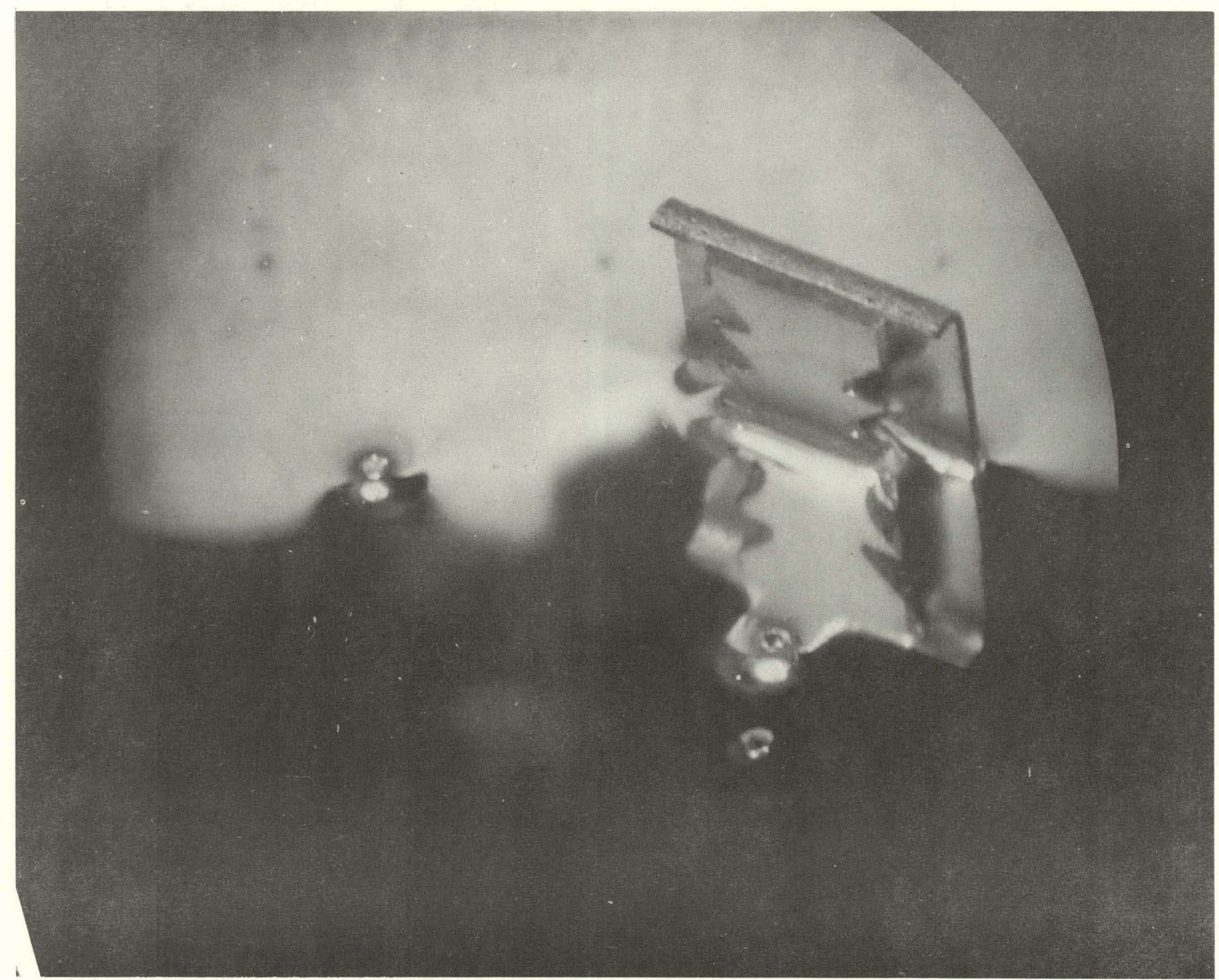

FIGURE 4-12. LEVEL GAUGE TEST FIXTURE - TWO ROD TOPS PROTRUDING ABOVE SODILM SURFACE 


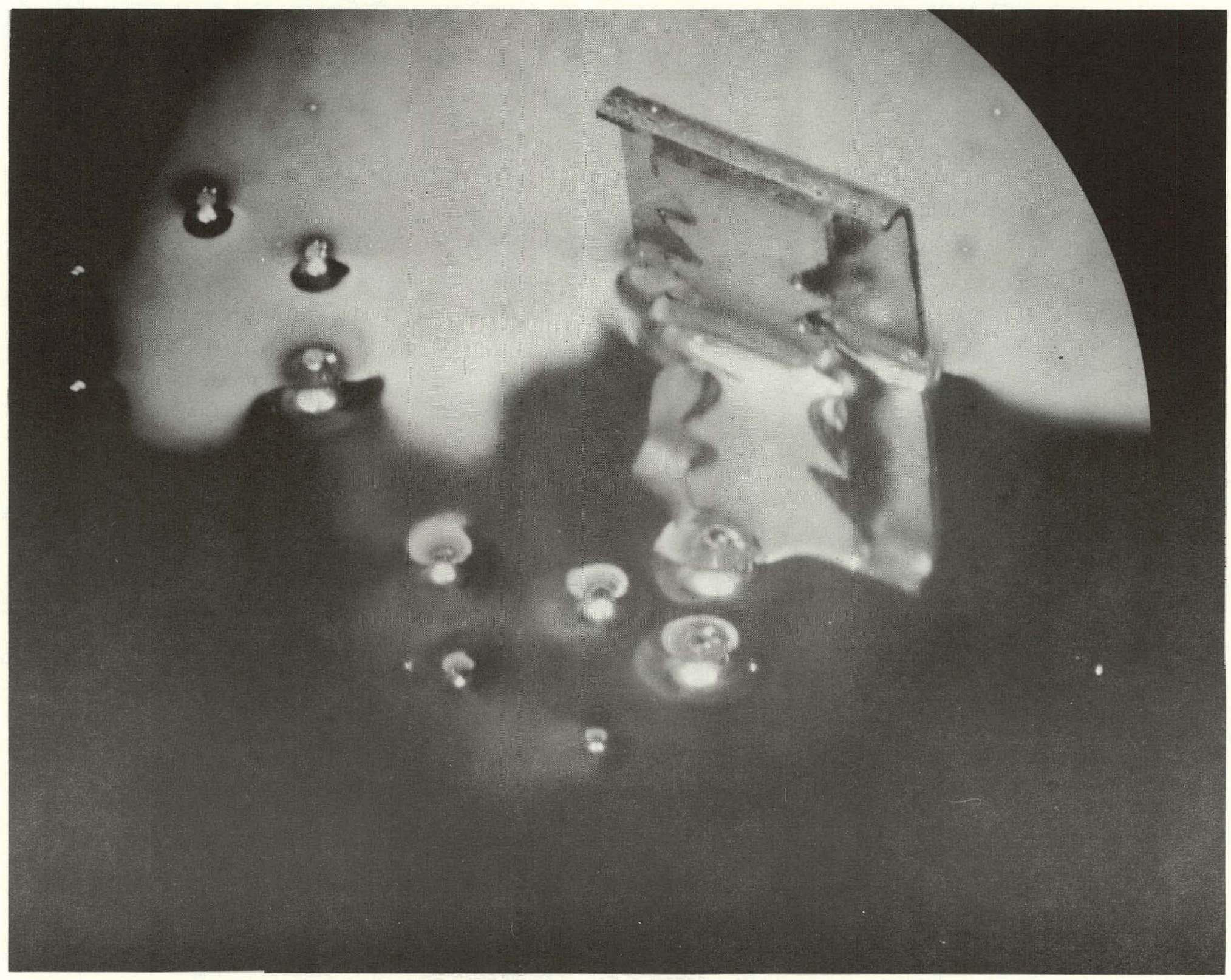


Figure 4-14 shows all seven rod tops exposed. In this photograph, the meniscus is well below the upper edge of the third tooth on the right, and thus more than 1/8-inch below this point. Since the fourth tooth on the left is not exposed, the level is known within a 1/8-inch range (the lower half of this 1/4-inch increment). The existence of the seventh rod protruding above the sodium surface (1/8-inch below the tooth) confirms the above observation.

Figure 4-15 is a photograph taken as the sodium was being lowered approximately 4 inches below the rod top elevation (note the light streaks due to the reflection of the changing sodium leve1). This photograph shows the four rod top configurations mentioned earlier. The slots milled down the side of the rod handles are not clearly discernible here. This is, however, due to the focusing problem when transferring the image to the camera mounted on the periscope. These fuel rod handle features were clearly discernible when viewing directly through the periscope.

Based on limited experience during the test period and the photographs discussed above, it is expected that fuel rod elevations can be readily confirmed within the 1/4-inch accuracy anticipated. The photographs clearly show the existence of handle tops as they protrude above the sodium level.

Direct mirror viewing is very adequate to quickly and thoroughly scan the top of the entire core region. The accuracy of the system thus results from how well the level gauge can be read by the operator. Reading the 1/4-inch increments on the level gauge is very easy since the periscope viewing provides a clear and essentially full-size image. Furthermore, with very limited experience, the meniscus effect and visual interpolation makes 1/8-inch level changes readily discernible. The tests revealed that the identifying features on the fuel rod handle were clearly discernible when viewing directly through the periscope. The photographs do not completely substantiate this due to focusing problems and light reflects unique to the photographs. Since the periscope viewing covers only about $40 \%$ of the core element handles, some other means süch as binoculars in conjunction with the mirror system will have to be used for confirmation of the various rod types with core position. 


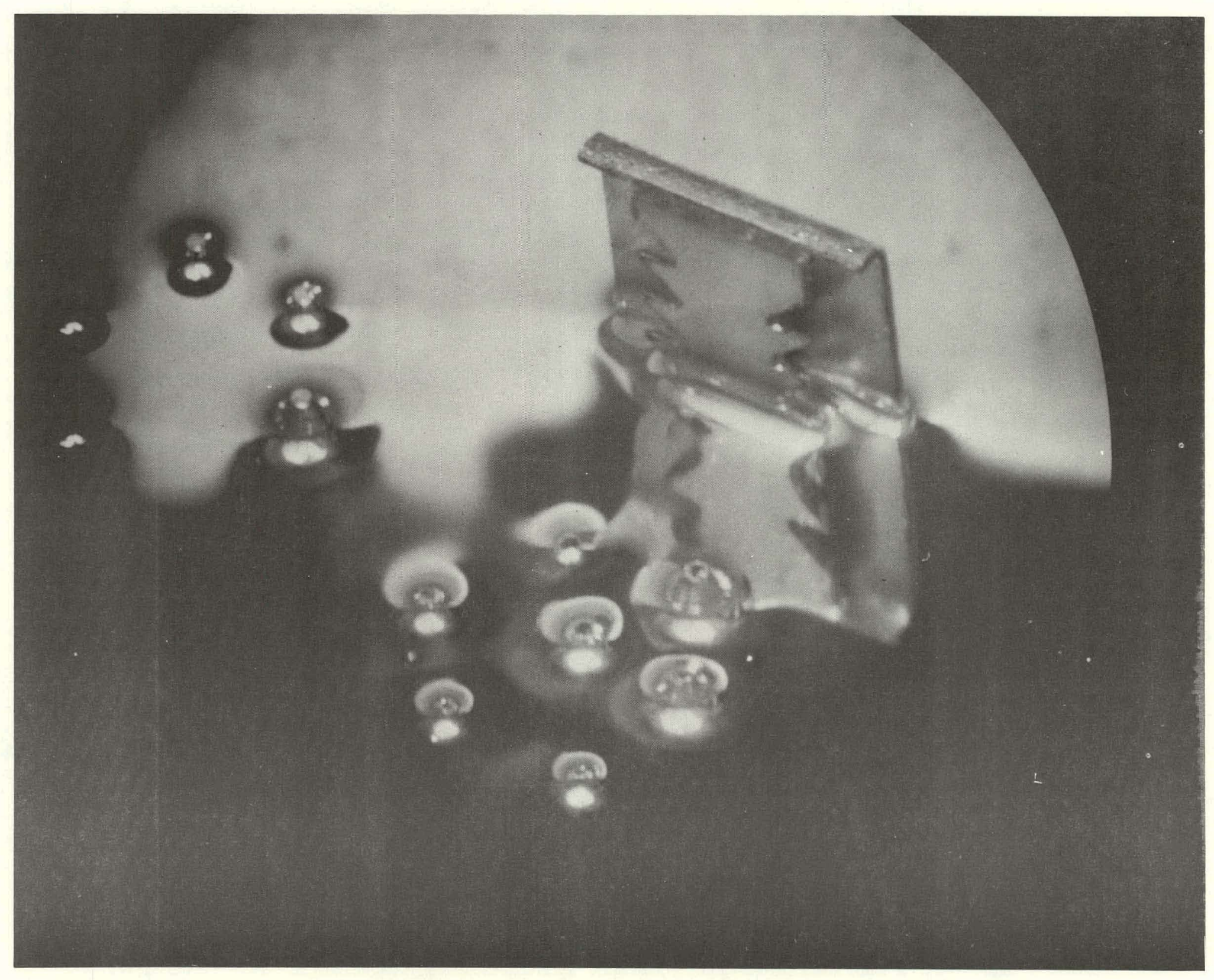




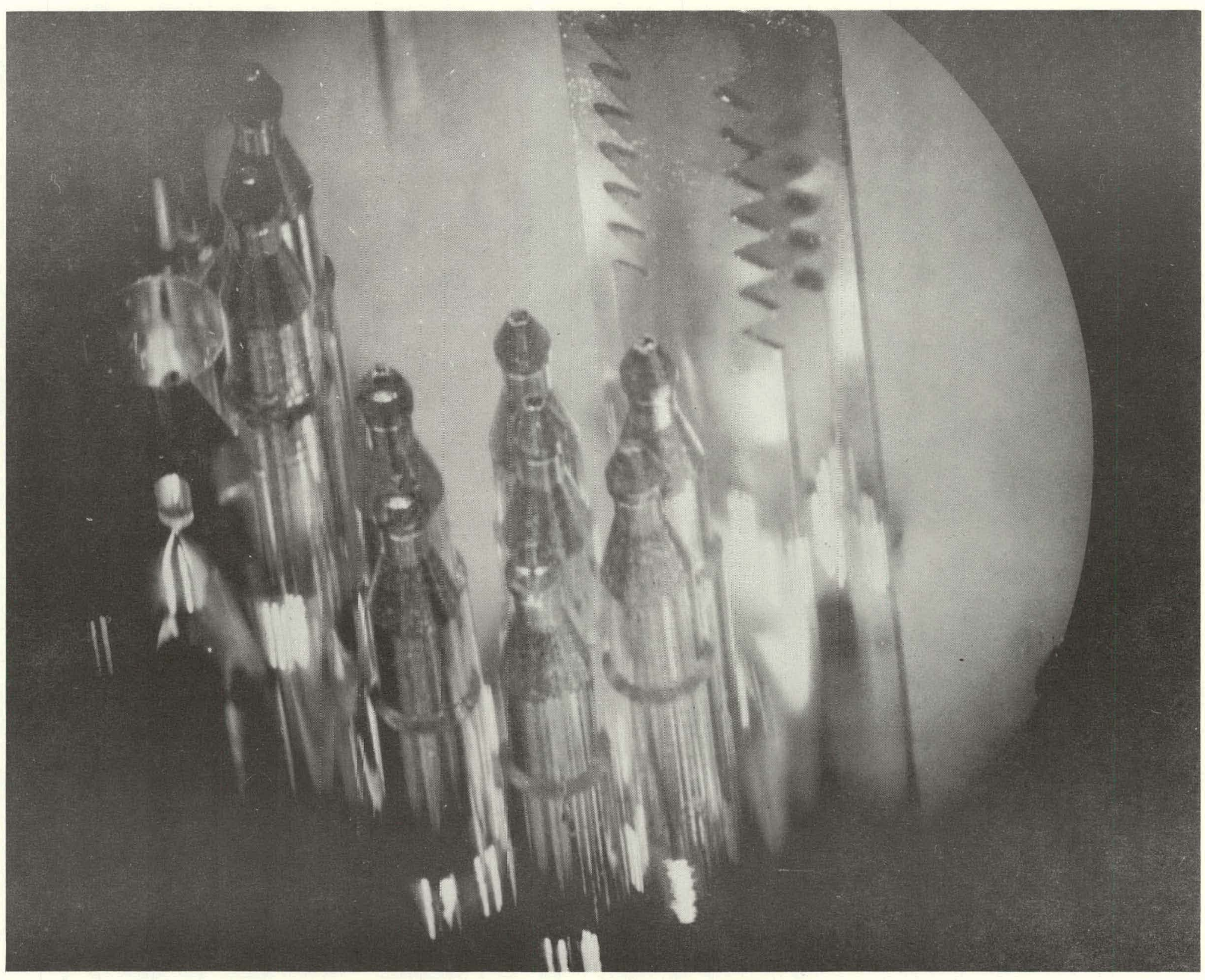

FIGURE 4-15. LEVEL GAUGE TEST FIXTURE - HANDLE REGIONS FULLY EXPOSED A3OVE SODIUM SURFACE 


\subsubsection{Refueling Cel1 Argon System}

The cell was first purged with nitrogen because of the cost differential between nitrogen and argon. The cell oxygen level was reduced to 7.5 percent and moisture to $600 \mathrm{ppm}$ with a one volume $\left(10,000 \mathrm{ft}^{3}\right)$ purge. The second nitrogen purge of approximately $30,000 \mathrm{ft}^{3}$ brought cell levels to 0.42 percent $\mathrm{O}_{2}$ and $225 \mathrm{ppm}_{2}$ ).

The argon purge with $12,000 \mathrm{ft}^{3}$ available commenced on March 16, 1967. The cell levels were 0.39 percent $\mathrm{O}_{2}$ and $300 \mathrm{ppm} \mathrm{H}_{2} \mathrm{O}$. At the completion of a one volume purge $\left(10,000 \mathrm{ft}^{3}\right)$ performed by 30 minute purges followed by 30 minute recirculation periods, the atmosphere in the cell was 33 percent $\mathrm{N}_{2}, 920$ ppm $\mathrm{O}_{2}$, and $290 \mathrm{ppm} \mathrm{H}_{2} \mathrm{O}$.

On Apri1 7, 1967, following the receipt of a tank trailer of argon, the final purge was started to reduce the $\mathrm{N}_{2}$ level to 5 percent and prepare for recirculation and purification to lower cell levels to specification limits of $10 \mathrm{ppm} \mathrm{H}_{2} \mathrm{O}$ and $\mathrm{O}_{2}$. (The heat exchanger capacity of the liquid argon tank limited the purge period to 30 minutes.) Initial levels were $8450 \mathrm{ppm} \mathrm{O}_{2}$, 12.1 percent $\mathrm{N}_{2}$. At the completion of the purge the cell levels were $2400 \mathrm{ppm}$ $\mathrm{O}_{2}$ and 3.5 percent $\mathrm{N}_{2}$. The purification system was put on the line and at the end of a 2-1/2 hour run the levels were $28 \mathrm{ppm}_{2}$ and $44 \mathrm{ppm} \mathrm{H} \mathrm{O} \mathrm{O}$. On April 10, 1967 the purification and recirculation system was started and after one hour cell levels were $70 \mathrm{ppm} \mathrm{O}_{2}, 29 \mathrm{ppm} \mathrm{H}_{2} \mathrm{O}$, and after another 2 hours, $18 \mathrm{ppm} 0_{2}, 17 \mathrm{ppm}$ $\mathrm{H}_{2} \mathrm{O}$. On April 13, 1967 the system was put on line and after 3 hours the first readings were $210 \mathrm{ppm} \mathrm{O}_{2}, 30 \mathrm{ppm} \mathrm{H}_{2} \mathrm{O}$. After another 3 hours of purification, cell levels were $14.7 \mathrm{ppm}_{2}, 18.7 \mathrm{ppm} \mathrm{H}_{2} \mathrm{O}$. The results of the tests clearly indicated that purging methods combined with the cell purification system can reduce $\mathrm{O}_{2}$ and $\mathrm{H}_{2} \mathrm{O}$ levels to acceptable values. 


\subsubsection{Sodium Vapor Deposition}

The operating requirements of the plant called for open pool refueling with sodium temperature in the 400 to $450^{\circ} \mathrm{F}$ range. The effect of sodium vapor deposition on the optical equipment was of prime importance since visual refueling is the operational concept. Vapor collectors in the form of $4 \times 6 \times 1 / 4-$ inch glass panes were located throughout the cell around the vessel and at each visual ald device. The vapor collectors and the cell.were subjected to 90 hours continuous exposure from the open pool, except for one mirror from each window removed after 45 hours exposure. These two mirrors had depositions of 0.1 and $0.15 \mathrm{mg}$ of sodium, north and west, respectively, revealing no significant difference between 45 and 90 hour exposure. These collectors located at the windows, periscope, mirrors had depositions of $0.1 \mathrm{mg}$ of sodium on their surface of 24 square inches or $4 \times 10^{-5} \mathrm{mg} / \mathrm{in}-\mathrm{h} r$. Deposition rates of this order of magnitude present no loss in visual acuity. 


\section{SECTION V}

CONCLUSION

The results of the operation of the SEFOR refueling cell mockup were generally satisfactory and provided excellent backup in support of the design. Equipment operation, remote handling techniques and procedures, and sodium vapor deposition information, were the objectives of the mockup. Some of the equipment did not adequately meet the intended objectives as discussed in Section IV. Modifications made to the equipment during the test perfod and those planned for the post-test period corrected the observed inadequacies.

The fact that in-cell repairs were feasible, visual coverage was satisfactory, and sodium vapor deposttion was negligible, reinforces the design concept of visual refueling and handling for a sodium-cooled fast reactor. In addition, the surface tension of liquid sodium near its melting temperature is apparently sufficient to make drippage from sodium-wetted vessel internals a negligible problem during movement about the cell interior. 


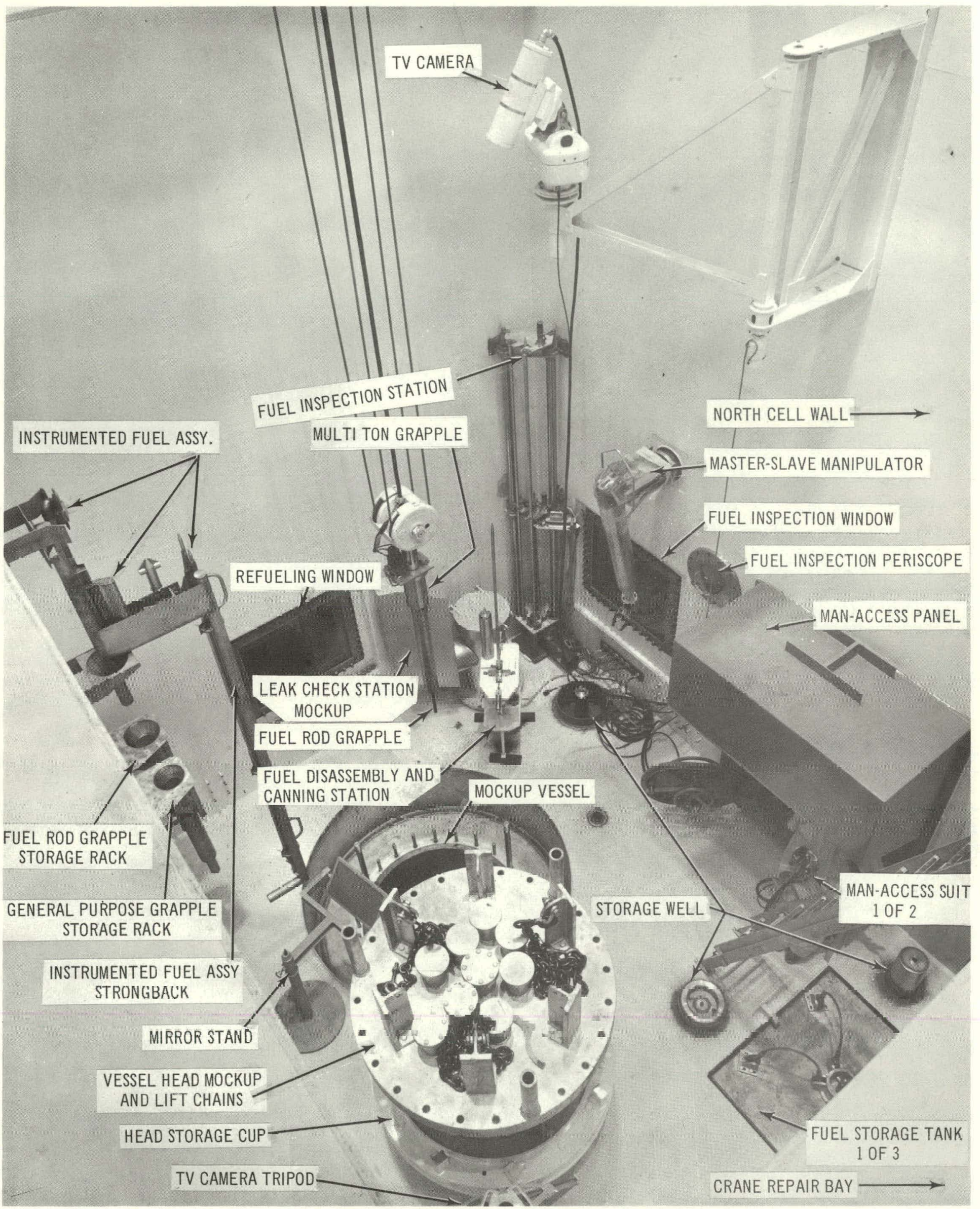


GEAP-5701

\section{REFERENCES}

1. Boelter, L.M.K, et al, "Free Evaporation into the Air of Water from a Free Horizontal Quiet Surface," Ind. Eng. Chem., 39, 6 (June, 1946). 
Mr. J. T. Jones, President

The Empire District Electric Co.

602 Joplin Street

Joplin, Missouri 64802

Mr. Harold E. Mortimer

Vice President

Assistant to Chairman of the Board

Gulf States Utilities Company

P. O. Box 2951

Beaumont, Texas 77704

Mr. C. F. Edwards, Vice President

Western Power Division

Central Telephone \& Utilities Corp.

P. O. Box 170

Great Bend, Kansas

Gesellschaft fur Kernforschung m.b.H.

Projekt Schneller Bruter

75) Karlsruhe, Germany

Postfach 947

Mr. A. Amorosi, Director

LMFBR Program Office

Argonne National Laboratory

South Cass Avenue

Argonne, Illinois 60439

Mr. M. A. Rosen

Asst. Director for Plant Engineering

DRD\&T, USAEC

Washington, D. C. 20545

Mr. E. E. Vintner

Asst. Director for Reactor Engineering

DRD\&T, USAEC

Washington, D. C. 20545

Brookhaven National Laboratory

Associated Universities, Inc.

Upton, Long Island, N. Y. 11973

Attn: Dr. C. H. Raseman

Mr. J. J. Morabito

Project Manager

Special Projects Branch

DRD\&T, USAEC

Washington, D. C. 20545

Mr. G. W. Evans, President

Kansas Gas and Electric Company

201. North Market Street

Wichita. Kansas 67201

\section{DISTRIBUTION}

1 Division of Technical Information Extension

U.S. Atomic Energy Commission

P. O. Box 62

Oak Ridge, Tennessee

1 Director

Research and Development Division

U. S. Atomic Energy Commission

Richland Operations Office

P. 0. Box 550

Richland, Washington 99352

$1 \quad$ Mr. G. Vendryes

Cen Saclay

Boite Postale 2

Gif-Sur-Yvette (S et $\mathrm{O}$ ) France

Dott, Ing. F. Pierantuni

4

10 CNEN

Viz Mazzini 2

Bologna, Italy

1 Mr. F. W. Lewis, President

Lousiana Power and Light Company

142 Delaronde Street

New Orleans, Louisiana 70114

Mr. R. C. Green, President

2 Missouri Public Service Co. 10700 East 50 Highway

Kansas City, Missouri

Mr. L. J. Cucullu, President

2 New Orleans Public Service Inc.

317 Baronne Street

New Orleans, Louisiana 70160

Mr. B. S. Jeffrey, President

Kansas Power and Light Company

808 Kansas Avenue

Topeka, Kansas 66601

Mr. J. Robert Welsh

1 Chairman of the Board

Southwestern Electric Power Company

P. O. Box 1106

Shreveport, Louisiana 71102

1 Mr. C. Weber, Chief

1
Fuel Fabrication Branch

DRD\&T, USAEC

Washington, D. C. 20545 
Power Reactor Development Company

1191 First Street

Detroit, Michigan 48226

Mr. E. R. Astley

Project Manager

FF'TF Project

Pacific Northwest Laboratory

Richland, Washington 99352

Mr. J. M. Simmons, Chief

Fuels and Materials Branch

DRD\&T, ISAEC

Washington, D. C. 20545

Mr. R. S. Boyd

Assistant Director for Reactor Projects

Division of Reactor Licensing

DRD\&T, USAEC

Washington, D. C. 2054.5

Director

Los Alamos Scientific Laboratory

Los Alamos, New Mexico 87544.

Dr. John C. Woodhouse

1 Guest Lane

Wilmington, Delaware 19809

Senior Representative

U.S. Mission to EURATOM Communities

c/o U.S. Embassy

Brussels, Belgium

General Directorate

Research and Training

EURATOM

51-53 Rue Belliard

Brussels, Belgium

Attn: A. DeStordeur

Mr. F. H. Coughlin, Chairman of Board

Central Louisiana Electric Co., Inc.

P. O. Box 111

Alexandria, Louisiana 71301

Mr. John Stewart, President

The Central Kansas Power Company

111 East 11th Street

Hays, Kansas 67601

Mr. Reeves Ritchie, President

Arkansas Power and Light Company

Ninth and Louisiana Street

Little Rock, Arkansas 72203
1 Mr. C. C. Czeschin, President

Arkansas-Missouri Power Company

104. South Fifth Street

Blytheville, Arkansas 72316

5

Mr. T. Flynn

Ebasco Services, Inc.

2 Rector Street

New York City 6, N. Y.

1 USAEC

Office of RDT Site Representative

310 DeGuigne Drive

Sunnyvale, California 94086

Attn: J. Levy

Dirtetor

Liquid Metals Information Center

P. O. Box 309

Canoga Park, California 91305

3

(Topicals only)

Mr. S. Golan, Project Manager

1000 MWe LMFBR Follow-On Study

1 Atomics International

P. O. Box 309

Canoga Park, California 91304

3

Mr. M. W. Croft, Project Manager

1000 MWe LMFBR Follow-On Study

The Babcock \& Wilcox Company

5061 Fort Avenue

P. O. Box 1260

10

Lynchburg, Virginia 24505

Dr. W. P. Staker, Project Manager

1000 MWe LMF BR Follow-On Study

Combustion Engineering, Inc.

P. O. Box 500

Windsor, Connecticut 06095

1. Mr. C. A. Andersun, Project Manager 1000 MWe LMFBR Follow-On Study Westinghouse Electric Corporation

Advanced Reactors Division Waltz Mill Site

$1 \quad$ P. O. Box 158

Madison, Pennsylvania 15663

Mr. L. W. Fromm, Manager

2
1 1000 MWe LMFBR Follow-On Study Project Building 208

Argonne National Laboratory

9800 South Cass Avenue

Argonne, Illinois 604.39 
Mr. L. F. C. Reichle

Ebasco Survices, Inc.

2 Rector Street

New York 6, New York

Mr. R. B. Wilson, President

Mississippi Power and Light Company

Electric Building

Jackson, Mississippi 39205

Mr. Ray W. Call, President

Missouri Utilities Company

400 Broadway

Cape Girardeau, Missouri 63701

Mr. W. A. Parker, President

Oklahoma Gas and Electric Company

321 North Harvey Street

Oklahoma City, Oklahoma 73101

Mr. D. J. Tuepker, Chairman

Public Service Company of Oklahoma 600 South Main Street

Tulsa, Oklahoma 74102

Dr. G. W. Wensch

Chief, Liquid Metal Project Branch

DRD\& $T$, USAEC

Washington, D. C. 20545
] Dr. J. A: Lieberman

Asst. Director for Nuclear Safety

DRD\&T, USAEC

Washington, D. C. 20545

1 Director, Contracts Division

2

U. S. Atomic Energy Commission

San Francisco Operations Office

2111 Bancroft Way

Berkeley, California 94704

1

F. W. Thalgott

- Associate Director, Idaho Division Argonne National Laboratory Box 1096

l.

Idaho Falls, Idaho 83401

Director, Argonne National Laboratory

9800 South Cass Avenue

Argonne, Illinois 60439

Attn: S. Lawrowshki

1

- Dr. I. Zartman, Chief

Reactor Physics Branch

1 DRD\&T, USAEC

Washington, D. C. 20545

1

USAEC Scientific Representative

United States Embassy

London, England 